\title{
Exploring the landscape and climatic conditions of Neanderthals and anatomically modern humans in the Middle East: the rodent assemblage from the late Pleistocene of Kaldar Cave (Khorramabad Valley, Iran)
}

Iván Rey-Rodríguez a,b *, Juan-Manuel López-García ${ }^{c, d}$, Hugues-Alexandre Blain $^{c, d}$, Emmanuelle Stoetzel ${ }^{a}$, Christiane Denys ${ }^{e}$, Mónica Fernández-García b,a , Laxmi Tumung ${ }^{\mathrm{c}, \mathrm{d}, \mathrm{a}}$, Andreu Ollé ${ }^{\mathrm{c}, \mathrm{d}}$, Behrouz Bazgir ${ }^{\mathrm{d}}$

a HNHP UMR 7194, CNRS / Muséum national d'Histoire naturelle / UPVD / Sorbonne Universités, Musée de l'Homme, Palais de Chaillot, 17 place du Trocadéro, 75016 Paris, France

${ }^{b}$ Sezione di Scienze Preistoriche e Antropologiche, Dipartimento di Studi Umanistici, Università degli Studi di Ferrara, C.so Ercole I d'Este, 32 - 44121 Ferrara, Italy

${ }^{c}$ Institut Català de Paleoecologia Humana i Evolució Social (IPHES). Zona Educacional 4, Campus Sescelades URV (Edifici W3) 43007 Tarragona, Spain

d Área de Prehistòria, Universitat Rovira i Virgili. Facultat de Lletres, Avinguda Catalunya 35, 43002 Tarragona, Spain

e ISYEB UMR 7205, CNRS / Muséum national d'Histoire naturelle / UPMC / EPHE / Sorbonne Universités, Paris, France

* corresponding author: ivan.rey-rodriguez@edu.mnhn.fr / ivanreyrguez@gmail.com (Iván Rey-Rodríguez)

\section{Abstract}

The Middle East, specially the Zagros region, lies in a strategic position as a crossroads between Africa, Europe and eastern Asia. The landscape of this region that prevailed around the Neanderthal and anatomically modern human occupations is not well known. Only a few sites have been studied in detail in this area, often providing only a faunal list. These reveal that Neanderthals and anatomically modern humans lived in a landscape mainly composed of dry steppes.

Here we extend the data obtained from Kaldar Cave through a systematic study of the rodent assemblage. The site provided evidence of a Pleistocene occupation attested by lithic tools associated with the Middle and Upper Palaeolithic, but it was also occupied during the Holocene, as evidenced by Neolithic artefacts. First excavations have revealed small vertebrates in Layer 4 (sub-layer 5 and 5II), belonging to the Upper Palaeolithic, and Layer 5 (sublayers 7 and $7 \mathrm{II}$ ), belonging to the Middle Palaeolithic.

The rodent assemblage of Kaldar Cave is mainly composed of six arvicoline, two cricetine, one glirid, one dipodid, one gerbilline and two murine species.

This assemblage shows that during the Late Pleistocene the environment around the site was mainly composed of open dry steppes, as indicated by the most abundant taxa, Microtus, Ellobius and Meriones. However, murine species indicate the presence of a vegetation cover. The palaeoclimatic conditions are characterised by lower temperatures and also less precipitation than at present.

The results obtained with the rodent assemblages show that there is no major palaeoenvironmental or palaeoclimatic change that would explain the 
cultural shift between Layer 5 (Middle Palaeolithic) and Layer 4 (Upper Palaeolithic).

Keywords: Rodentia, Middle East, taxonomy, palaeoecology, human occupations

\section{Introduction}

Small vertebrates are recognized to be good palaeoecological indicators due to their rapid evolution, the limited geographic range of a species and unique niche requirements, as well as their frequent preservation in archaeological and palaeontological sites. They might be excellent indicators of palaeovegetation type and provide a high-resolution proxy for palaeoenvironmental changes (e.g. Belmaker and Hovers, 2011). Studies of small vertebrates from archaeological sites in the Middle East are still scarce (Belmaker and Hovers, 2011; Belmaker et al., 2016; Demirel et al., 2011; Fernández-Jalvo, 2016a; Kandel et al., 2017; Maul et al., 2015a, 2015b; Smith et al., 2015; Weissbrod and Zaidner, 2014), and they mainly propose preliminary lists of taxa. On the other hand, some studies of extant owl pellet assemblages have been performed in the Middle East (Abi-said et al., 2014; Darvish et al., 2000; Haddadian Shad et al., 2014; Kopij and Liven-schulman, 2013; Obuch and Khaleghizadeh, 2012; ReyRodríguez et al., 2019; Shehab et al., 2013), providing taxonomic and some taphonomic reference data in Iran, Lebanon, Israel, Turkey and Syria.

The main palaeoecological and palaeoclimatic reconstructions based on faunal assemblages relate to the unique niche requirements of a particular species. Belmaker et al. (2011) pointed out that their interpretations, in contrast, are based on analyses of community composition. Analyses of persistence versus change over time should take into account species presence-absence, rank abundance and proportional abundance (Belmaker and Hovers, 2011).

The Middle East is a prime location to study Neanderthal and anatomically modern human (AMH) interactions during the Middle to Upper Palaeolithic transition (Belmaker et al., 2016). However, sites yielding evidence of both Neanderthal and $\mathrm{AMH}$ occupations in the same sequence are rare, only five sites were well excavated (Bazgir et al., 2014; Bazgir et al., 2017). In this framework, Kaldar Cave is a key archaeological site for evaluating the influence of environment on cultural changes in both human species because of its location and the faunal and lithic remains. The main objective of this paper is to infer the landscape composition and the climatic conditions in which Neanderthal and AMH populations pursued their activities through the study of small mammals. We identify and describe the rodent fossils recovered from Kaldar Cave in order to establish the main criteria for further identifications in this region and provide a preliminary basis for future systematic studies. 


\section{Kaldar Cave}

Kaldar Cave is located in the northern part of the Khorramabad valley, Lorestan Province, western Iran (4817'35" E, 333'ㄷ” N) at 1290 m a.s.l. (Fig. 1a,b). The cave was discovered in 2007, and the first archaeological intervention was undertaken by an Iranian-Spanish team in 2011-2012, revealing the great potential of the cave (Bazgir et al., 2014). A second excavation was performed in 2014-2015. The trench exposed an approximately $2 \mathrm{~m}$-thick section of sedimentary deposits, characterized by 5 main layers, themselves divided into several sub-layers (Fig. 1C).

Layer 5 (including sub-layers 7 and 7II) consists of an extremely cemented reddish-brown sediment with some small angular limestone blocks and Middle Palaeolithic artefacts with Levallois elements. So far, no chronometric data are available for this layer (Bazgir et al., 2017).

Layer 4 (including sub-layers 5, 5II, 6 and 6II) consists of a silty but compact dark-brown sediment with cultural remains attributed to the Upper and early Upper Palaeolithic. In the uppermost parts of this layer, two fireplaces made of clay were recovered and dated through thermoluminescence, yielding ages that ranged from 23,100 \pm 3300 to 29,400 $\pm 2300 \mathrm{BP}$ (Bazgir et al., 2017). The dates obtained show that these fireplaces were made or re-used from existing older sediment from the upper part of this layer in the later stages of the Upper Palaeolithic. AMS radiocarbon dates of $38,650-36,750 \mathrm{cal}$ BP, 44,200-42,350 cal BP, and 54,400-46,050 cal BP have been obtained from charcoal material located below this layer (Bazgir et al., 2017; Becerra-Valdivia et al., 2017).

Layers 1 to 3 (including sub-layers 4 and 4II) consist of ashy sediments of a blackish-green colour containing both thick and thin angular limestone clasts. These layers varied in thickness from 60 to $90 \mathrm{~cm}$ and contained many phases dating to the Holocene: Islamic and historical eras, Iron Age, Bronze Age, Chalcolithic and Neolithic. However, due to the presence in these layers of bioturbation mainly by burrowing animals, the phases were recognized only by a preliminary study of the potsherds, metal artefacts and some diagnostic lithic artefacts from the lower layers.

This site provides evidence for the Middle to Upper Palaeolithic transition in the Middle East (Bazgir et al., 2017). Moreover, Kaldar Cave has yielded the oldest evidence of Prunus spp. in the area, through the study of thirty charcoal remains (Allué et al., 2018), that helps us to reconstruct the environmental conditions, evidencing a wooded vegetation.

\section{Material and methods}

The rodent fossil remains used in this study, 1112 molars, come from the archaeological excavation campaigns carried out in Kaldar Cave in 2011-2012 and 2014-2015. 
The samples comprise disarticulated bones and isolated teeth that were collected in the field by water screening using superimposed 5 and $0.5-\mathrm{mm}$ mesh screens.

\subsection{Taxonomy}

In this article we only focus on rodents, because these are one of the most useful tools for palaeoenvironmental and palaeoclimatic reconstructions of archaeological sites, and the other material, as amphibians, squamates, birds, shrews and bats, will be studied later. The taxonomic identification of the rodent remains is based mainly on molar morphology and measurements of the lower $\mathrm{m} 1$, the taxonomically most diagnostic tooth.

The remains were identified at a specific level whenever possible, thanks to comparisons with reference collections from the Natural History Museum of London (NHM) and comparative morphological and biometric data from the literature, notably for Microtus (Coşkun, 2016; Kryštufek and Shenbrot, 2016; Kryštufek and Vohralík, 2009; López-García, 2011; Rusin, 2017; Shenbrot, Kryštufek et al. 2016; Tesakov, 2016), Cricetulus (Bogicevic et al., 2011; Kryštufek et al., 2017; Sándor, 2018), Mesocricetus (Kryštufek and Vohralík, 2009), Meriones (Coşkun, 1999; Darvish, 2011; Dianat et al., 2017; Kryštufek and Vohralík, 2009; Souttou and Denys, 2012; Stoetzel et al., 2017), Allactaga (Karami et al., 2008; Shenbrot, 2009), Myomimus (Gerrie and Kennerley, 2017; Karami et al., 2008; Kennerley and Kryštufek, 2019), Apodemus (Amori et al., 2016; Bogicevic et al., 2011; Knitlová and Horáček, 2017; Kryštufek and Vohralík, 2009; López-García, 2008) and Mus (Darviche et al., 2006; Kryštufek and Vohralík, 2009; Siahsarvie and Darvish, 2008).

Quantification of taxonomic frequencies was based on standard measures in zooarchaeological analyses, including the number of identified specimens (NISP) and minimum number of individuals (MNI) (Weissbrod and Zaidner, 2014). This latter was estimated using the most abundant skeletal element present in the assemblage (molars in our case).

\subsection{Taphonomic remarks}

A preliminary study was performed on the Kaldar Cave micromammal remains. This was based on the systematic descriptive method that examines the modifications of prey bones induced by predation, focusing on the degree of digestion observed in teeth during the identification (Andrews, 1990; Fernández-Jalvo et al., 2016). This study showed a significant number of digested teeth (Bazgir et al., 2017), indicating that predation activity was the origin of at least part of the accumulation. According to the different degrees of digestion (mostly light, moderate and, heavy in a few cases) observed in the molars, the predator responsible for this accumulation could be a category 3 predator such as the tawny owl (Strix aluco) or the Eurasian eagle owl (Bubo 
bubo). Both species are currently present in the area, have opportunistic hunting habits, and are sedentary, so their prey spectrum is assumed to be a good representation of the ecosystem in which they live.

\subsection{Palaeoenvironmental and palaeoclimatic reconstructions}

\subsubsection{Habitat weighting method}

Palaeoecological interpretations derived from faunal data are based on analyses of community composition (Belmaker and Hovers, 2011). The method used for the palaeoenvironmental reconstruction is the habitat weighting method, also named the taxonomic habitat index (Evans et al., 1981; Andrews, 2006; modified by Blain et al., 2008; López-García et al., 2011), which is based on the current distribution of each taxon in the habitat(s) where it can be found nowadays. We assume that the Kaldar Cave species had equivalent ecological requirements to their present-day relatives, because the Late Pleistocene species are the same as those today and no extinct fossil species are found in the assemblage. We adapt the method to our studied area, differentiating the following types of habitats: Forest (Fo), a large area covered with trees; Shrubland (Sh), vegetation dominated by shrubs; Grassland (Gr), an open area covered with grass; Desert (De), an area with little precipitation and no vegetation cover; Wetland (We), an area where water covers the soil; Steppe (St), a dry grassy plain; and Rocky (Ro), a rocky or stony substrate. Each species has a score of 1.00 , which is divided between the habitats where the species can be found at present (Table 1), all the species ranges were taken from the IUCN Red List of Threatened Species (https://www.iucnredlist.org/resources/spatial-data-download).

\subsubsection{Bioclimatic Model}

In order to reconstruct the climate at Kaldar Cave, we applied the bioclimatic model (BM), which was developed by Hernández-Fernández (2001) on the basis of the faunal spectrum, assuming that small- and large-mammal species can be ascribed to ten different climates (Hernández-Fernández, 2001; Hernández-Fernández and Peláez-Campomanes, 2003; Hernández-Fernández et al., 2007). It was first necessary to calculate the climatic restriction index $\left(\left.C R\right|_{l}=1 / n\right.$, where $i$ is the climatic zone where the species appear and $n$ is the number of zones where the species is present) and the bioclimatic component $\left(\mathrm{BC}_{i}=\left(\Sigma \mathrm{CRI}_{i}\right) 100 / S\right.$, where $i$ is the climatic zone and $S$ is the number of species). To BC a mathematical model is applied as a regression that allows us to calculate climatic parameters (see Appendix 1).

The different climatic groups defined by Hernández-Fernández (2001) and Hernández-Fernández et al. (2007) are: I equatorial; II tropical with summer rains; II/III transition tropical semiarid; III sub-tropical arid; IV, subtropical with 
winter rains and summer droughts; V, warm temperate with not very severe winters but high humidity; VI, typical temperate with winters that are cold but not very long, but summers that are cool; VII, arid-temperate with large temperature contrasts between winter and summer; VIII, cold-temperate with cool summers and long cold winters (boreal) and IX, artic (Table 2).

By means of the $B M$ we were able to estimate the mean annual temperature (MAT), the mean temperature of the coldest month (MTC), the mean temperature of the warmest month (MTW) and the mean annual precipitation (MAP). This method also allowed us to assess whether there were changes in the temperature and precipitation regimes during the Middle to Upper Palaeolithic transition at Kaldar Cave.

\section{Results and discussion}

\subsection{Taxonomic identifications}

In total 264 minimum number of individuals (MNI) were identified (Table 3 and Fig. 2). Some differences were found with respect to the preliminary list previously published by Bazgir et al. (2017). We notably found some new specimens and reconsidered the identifications for Ellobius talpinus, Calomyscus sp. and Dryomys cf. nitedula.

\section{Order Rodentia Bowdich, 1821}

Rodentia indet.

There are 14 teeth (11 in Layer 4 and 3 in Layer 5 ) that have not been identified to the family or genus level because they were broken.

Family Cricetidae Fisher, 1817

Subfamily Arvicolinae Gray, 1821

Genus Microtus Schrank, 1798

Microtus spp.

Material: 554 isolated teeth. Layer 1-3: four isolated teeth; three left lower $\mathrm{m} 1$ and one right lower m1. Layer 4: 258 isolated teeth; $81 \mathrm{~m} 2 ; 101 \mathrm{~m} 3,13$ right upper M1, 31 right lower $\mathrm{m} 1$; four left upper M1 and 28 left lower $\mathrm{m} 1$. Layer 5: 292 isolated teeth; $119 \mathrm{~m} 2 ; 53 \mathrm{m3}$; nine left upper M1, 51 left lower $\mathrm{m} 1 ; 10$ right upper $\mathrm{M} 1 ; 50$ right lower $\mathrm{m} 1$.

\section{Microtus socialis Pallas, 1773}

Material: 74 isolated teeth. Layer 1-3: three isolated teeth, three right lower $\mathrm{m} 1$. Layer 4: 36 isolated teeth; 20 right lower $\mathrm{m} 1$ and 16 left lower $\mathrm{m} 1$. Layer 5: 35 isolated teeth; 20 right lower $\mathrm{m} 1$ and 15 left lower $\mathrm{m} 1$. 
Material: 15 isolated teeth. Layer 1-3: one isolated tooth, one right lower m1. Layer 5: 14 isolated teeth; nine right lower $\mathrm{m} 1$ and five left lower $\mathrm{m} 1$.

\section{Microtus quentheri Danford \& Alston, 1880}

Material: 17 isolated teeth. Layer 1-3: one isolated tooth, one left lower $\mathrm{m} 1$. Layer 4: 16 isolated teeth; nine right lower $\mathrm{m} 1$ and seven left lower $\mathrm{m} 1$.

Description and discussion: all the molars are hypsodont and arhizodont with crown cementum in the re-entrant angles. The enamel differentiation is Microtus-like. Six extant species of Microtus have been identified in Iran: Microtus arvalis, Microtus irani, Microtus kermanensis, Microtus socialis, Microtus transcaspicus and Microtus guentheri (Aşan Baydemir and Duman, 2009; Golenishchev et al., 2019; Firouz, 2005).

Microtus $\mathrm{m} 1$ are characterized by four buccal and five lingual re-entrant angles (Kryštufek and Vohralík, 2009; Tsytsulina et al., 2017) with a posterior lobe (PL), seven triangles ( $T$ ) and an anterior cap (AC). We identified the Kaldar specimens on the basis of their measurements (Table 4), the arrangement and morphology of the triangles, and the AC (which may or may not be connected with the other elements).

In our sample we identified Microtus spp., Microtus socialis, Microtus guentheri and Microtus irani.

In Microtus socialis, the triangles from T1-T5 are closed, but T6-T7 are parallel and broadly confluent with the AC. Microtus guentheri is distinguishable from Microtus socialis by the rounded shape of the AC, which is of an arhombomorph type (Aşan Baydemir and Duman, 2009), and also by T6-T7, which are separated from the AC. In accordance with the measurements given in Aşan Baydemir et al. (2009), the size of Microtus guentheri and Microtus socialis is similar. In Microtus irani, triangles T1-T5 are closed, but T6-T7 are open and not parallel with one another; moreover, Microtus irani is clearly larger than the other species considered in our reference collection and also in our sample. Finally, we include in Microtus spp. all the elements that we cannot attribute to one species or another, in particular because of their bad state of preservation (due to digestion, breakage).

Habitat and distribution: Microtus irani occupies grasslands in Iran, Turkey and the Caucasus (Kryštufek and Kefelioğlu, 2001).

Microtus socialis is found in Russia, Ukraine, the Caucasus, Transcaucasia, Turkestan, Iran and Afghanistan (Tsytsulina et al., 2017), although the range is fragmented. It is a highly colonial species, found in steppe habitats and also in agricultural lands, but extending also to bushy scrubs and uncultivated mountain valleys, as well as to open oak forests on dry hillsides (Tsytsulina et al., 2017). 
Microtus guentheri occurs from the southeastern Balkans and Turkey through Syria, Lebanon and Israel, with an isolated range segment in northern Libya, Iran and some parts of Europe (Aşan Baydemir and Duman, 2009). This species is present in dry grasslands with sparse vegetation (Amr, 2015).

\section{Genus Chionomys Miller, 1908} Chionomys nivalis Martins, 1842

Material: 25 isolated teeth. Layer 1-3: two isolated teeth; one left lower $\mathrm{m} 1$ and one right lower $\mathrm{m} 1$. Layer 4: 17 isolated teeth; 12 right lower $\mathrm{m} 1$; five left lower m1. Layer 5: six isolated teeth; three left lower m1; three right lower m1.

Description and discussion: in our specimens it can be observed that the first lower molars display five triangles and that the morphology of the anteroconid complex (AC) is characteristic of the nivalis morphotype, where triangles T6 and T7 are absent and the anterior cap is of an arrowhead or oval shape, inclined towards the labial part. The enamel is of the Microtus type with cement (Krystufek, 2017; Kryštufek and Vohralík, 2009; López-García, 2011). These specimens differ from Microtus in that they only have five triangles, and the morphology of the AC is the other main characteristic of this species that helps us to differentiate it from Microtus.

Habitat and distribution: Chionomys nivalis has a global distribution extending from southwestern Europe through southeastern Europe to the Caucasus, Turkey, Israel, Lebanon, Syria and Iran. In Iran it is distributed in the north and also in the west (Shenbrot and Krasnov, 2005; Krystufek, 2017). This is the only Chionomys species occurring today in Iran, but two other species $(C$. gud, C. roberti) are represented a little further north (northeastern Turkey, southern Georgia).

Regarding its habitat, it is present in open rocky areas, typically above the tree line and with scarce vegetation cover (Amori, 1999).

\section{Genus Ellobius Fischer, 1814}

\section{Ellobius spp.}

Material: 173 isolated teeth. Layer 1-3: two isolated teeth; two left lower m1. Layer 4: 91 isolated teeth; seven indet.; eight right lower $\mathrm{m} 1$; five left lower $\mathrm{m} 1$; 11 upper M1; $43 \mathrm{~m} 2 ; 17 \mathrm{~m} 3$. Layer 5: 80 isolated teeth; seven left lower m1; three upper M1; $45 \mathrm{~m} 2 ; 25 \mathrm{~m} 3$.

\section{Ellobius fuscocapillus Blyth, 1843}

Material: 11 isolated teeth. Layer 1-3: one isolated tooth; one right lower m1. Layer 4: five isolated teeth; two right lower $\mathrm{m} 1$; three left lower $\mathrm{m} 1$. Layer 5: five isolated teeth; four left lower $\mathrm{m} 1$ and one right lower $\mathrm{m} 1$. 
Material: 20 isolated teeth. Layer 4: 10 isolated teeth; seven right lower m1 and three left lower m1. Layer 5: 10 isolated teeth; four left lower $\mathrm{m} 1$ and six right lower $\mathrm{m} 1$.

Description and discussion: 204 isolated teeth show the typical traits of the genus Ellobius (Miller, 1896; Hinton, 1962, Kretzoi, 1969; Coşkun, 2016; Kryštufek \& Shenbrot, 2016; Kryštufek and Vohralík, 2009; Rusin, 2017; Shenbrot et al., 2016; Tesakov, 2016). Ellobius molars are notably characterized by the presence of roots that are well visible in adults and old individuals, but not always apparent in young specimens (Coşkun, 2016). Moreover, Ellobius molars lack cement in the re-entrant angles. The Ellobius $\mathrm{m} 1$ is composed of the anterior cap (AC), five triangles $(\mathrm{T})$ with three buccal and four lingual salient angles, and one posterior lobe (PL). Both M3 and $\mathrm{m} 3$ are reduced and smaller than the other molars, with three triangles on the labial side and two triangles on the lingual side. M1 has three inner and outer folds, and M2 and M3 have two inner and two outer re-entrant folds. The first and second upper molars have three triangles on the lingual and labial sides. However, the re-entrant angle between the first and the second triangles on the lingual side is more superficial (Gharkheloo and Kıvanç, 2003).

In Iran, the genus Ellobius is currently represented by three species: Ellobius fuscocapillus, Ellobius lutescens and Ellobius talpinus (Firouz, 2005; Kryštufek \& Shenbrot, 2016; Kryštufek and Vohralík, 2009; Moradi Gharkheloo, 2003; Rusin, 2017; Shenbrot et al., 2016). The $\mathrm{m} 1$ is quite similar among these species, but there are some differences that can help us to differentiate them.

The AC is broad in Ellobius lutescens, narrow in Ellobius talpinus and elongated in Ellobius fuscocapillus (Maul et al., 2015b). The distance between T4 and T5 (W) and the total length (L) differ among the species (Table 5). We have observed in modern specimens from the Natural History Museum of London that Ellobius fuscocapillus is the largest and Ellobius talpinus the smallest.

In our sample we identify as Ellobius spp. those $\mathrm{m} 1 \mathrm{~s}$ that are too broken or digested to distinguish, as well as all the m2, m3, M1, M2 and M3 because of the lack of discriminant characters. The identification of Ellobius lutescens and Ellobius fuscocapillus in the Kaldar material is based on the morphology of the $A C$ and the measurements ( $L$ and $W$ ). We do not identify Ellobius talpinus in our sample, as no specimen displays morphological features characteristic of this species, such as the narrow AC, and because the measured specimens are larger than E. talpinus.

Habitat and distribution: Ellobius species frequent steppes, grasslands and semi-deserts in eastern Europe and central Asia; these fossorial species are specialised in subterranean life (Coşkun, 2016; Kryštufek and Vohralík, 2009). Ellobius lutescens is a Palaearctic species distributed across Iran, Iraq, Azerbaijan, Armenia, Transcaucasia and East Anatolia (Thomas, 1905; Ellerman and Morrison-Scott, 1951; Darlington, 1957; Osborn, 1962; Walker, 
1964; Lay, 1967; Hassinger, 1973; Roberts, 1977; Corbet, 1978; Corbet and Hill, 1991; Wilson and Reeder, 2005; Coşkun, 1997, 2016; Nowak, 1999; Kryštufek \& Shenbrot, 2016). In Iran, this species is found in mountain grasslands, sandy semi-deserts and steppe areas (Kryštufek \& Shenbrot, 2016; Tesakov, 2016). Ellobius fuscocapillus shows a wide range across eastern Iran, Turkmenistan, Afghanistan and Pakistan. In Iran it is found in open steppes with loose soil (Shenbrot, Kryštufek \& Molur, 2016).

\section{Subfamily Cricetinae Fischer, 1817 Genus Cricetulus Milne-Edwards, 1867 Cricetulus migratorius Pallas, 1773}

Material: 19 isolated teeth. Layer 1-3: one isolated tooth; one right lower m3. Layer 4: 13 isolated teeth; three left lower $\mathrm{m} 1$, two left upper M2; three right lower $\mathrm{m} 1$, three right upper M1 and two right upper M2. Layer 5: five isolated teeth; three left lower $\mathrm{m} 1$ and two right lower $\mathrm{m} 1$.

Description and discussion: the first molars ( $\mathrm{m} 1$ and $\mathrm{M} 1$ ) are brachyodont and cuspidate, with two longitudinal series of cusps. Each series of cusps consists of three pairs. The $\mathrm{m} 1$ and $\mathrm{M} 1$ are the largest and the m3/M3 the smallest. The lower m3 only has two pairs of cusps (Kryštufek and Vohralík, 2009). We identify Cricetulus migratorius in all the layers of Kaldar Cave in accordance with the measurements and identification keys for molars based on the morphology and arrangement of the tubercles and cusps provided by Kryštufek and Vohralík (2009). We also draw comparisons with the reference collection from Iran, Afghanistan and Azerbaijan housed in the Natural History Museum of London. The grey hamster, or migratory hamster, is the smallest hamster species (Bogicevic et al., 2011; Sándor, 2018).

Habitat and distribution: Cricetulus migratorius extends from eastern Europe through Russia and central Asia to Mongolia and western China (Kryštufek et al., 2017; Kryštufek and Vohralík, 2009). In Iran, this species is found all over the country. The habitats of this species are mostly dry grasslands, steppes and semi-deserts. Arid areas with relatively sparse vegetation are preferred (Kryštufek et al., 2017; Maul et al., 2015a).

\section{Genus Mesocricetus Nehring, 1898 Mesocricetus brandti Nehring, 1898}

Material: 10 isolated teeth. Layer 4: three isolated teeth; one left upper M1, one right lower $\mathrm{m} 1$ and one right upper M1. Layer 5: seven isolated teeth; four left upper M1, one right upper M2 and two right upper M1.

Description and discussion: the specimens from Kaldar Cave are attributed to Mesocricetus brandti on the basis of the size and morphology of the teeth. The molars present a similar morphological pattern to Cricetulus migratorius, but are significantly larger in size. The first molars have six 
tubercles, the second and third molars only four. The largest molars are $\mathrm{m} 1$ and $\mathrm{M} 1$, whereas m2/M2 and m3/M3 are reduced (Kryštufek and Vohralík, 2009). In Iran we also find Mesocricetus raddei, which presents a similar morphology of the teeth to Mesocricetus brandti, but compared with the NHM reference collection of the latter, Mesocricetus raddei is bigger

Habitat and distribution: Mesocricetus brandti has the largest distributional area of the species belonging to the genus Mesocricetus, ranging from Anatolia, Transcaucasia (Armenia, Georgia and Azerbaijan) and southeast Dagestan to northwest Iran (Qazvin in the east, Lorestan in the south; Lay, 1967). This species is found at altitudes from sea level up to $2,600 \mathrm{~m}$. However, the primary range is from 1,000-2,200 m. Mesocricetus brandti is found in arid and semiarid steppe habitats in lowlands and in mountainous areas (Kryštufek et al., 2015; Kryštufek and Vohralík, 2009; Neumann et al., 2017).

\section{Family Muridae Illiger, 1811 Subfamily Gerbillinae Gray, 1825 Genus Meriones, Illiger 1811 Meriones cf. persicus Blanford, 1875}

Material: 157 isolated teeth. Layer 1-3: three isolated teeth; two left upper $\mathrm{M} 1$ and one right lower m1. Layer 4: 65 isolated teeth; $21 \mathrm{~m} 2$; four m3; 17 left lower $\mathrm{m} 1$; eight right upper $\mathrm{M} 1$, five left upper $\mathrm{M} 1 ; 10$ right lower $\mathrm{m} 1$. Layer 5: 88 isolated teeth; eight $\mathrm{m} 3 ; 21 \mathrm{~m} 2 ; 18$ left lower m1, 10 left upper M1, 16 right upper M1 and 15 right lower $\mathrm{m} 1$.

Description and discussion: the genus Meriones is one of the most diverse among the tribe Gerbillini in the Palaearctic region, particularly in arid regions of Asia (Darvish et al., 2011; Denys, 2017). The Meriones species reported in Iran are: Meriones crassus, Meriones hurrianae, Meriones lybicus, Meriones meridianus, Meriones persicus, Meriones tristrami, Meriones vinogradovi and Meriones zarudnyi (Darvish, 2011; Dianat et al., 2017; Kryštufek and Vohralík, 2009; Souttou and Denys, 2012).

The material from Kaldar Cave attributed to the genus Meriones displays the typical morphology of this group, including semi-hypsodont molars with prismatic enamel triangles linked by a longitudinal crest and with no trace of cusps. In our sample, we identify first upper molars (M1) with three roots, which is characteristic of Meriones persicus and Meriones tristrami. Unfortunately, the dental morphology of Meriones persicus and Meriones tristrami is very similar; there are three roots in $\mathrm{m} 1$, the second molars have two transverse plates and two roots, whereas the third molars are simple and rounded with a single root (Coşkun, 2016; Kryštufek and Vohralík, 2009).

Given its current distribution and the morphological traits observed in the reference collection from Iran, Azerbaijan and Pakistan housed in the Natural History Museum of London, we provisionally attribute our specimens to Meriones cf. persicus, especially in the light of the number of roots and the 
morphology of M1 and m1, pending a revision of the Middle Eastern species of the genus.

Habitat and distribution: the genus Meriones is distributed across North Africa, Central Asia, Transcaucasia, Turkey and Pakistan (Darvish et al., 2014; Stoetzel et al., 2017). It lives mostly in dry steppes of short or tall grass, on open hillside, among rocky outcrops in desolate steppes, or in open dry meadows. The distribution of Meriones persicus ranges from the Caucasus (including the southeastern foothills of the Lesser Caucasus and the Talysh Plateau in Azerbaijan) in the west, through northeastern Iraq and Iran to Turkmenistan, Afghanistan (Habibi, 2004) and Pakistan, where it is widely distributed. It generally occurs in arid, rocky or mountainous regions (Kryštufek and Vohralík, 2009; Molur \& Sozen, 2016).

\section{Family Dipodidae Fischer, 1817 Genus Allactaga Cuvier, 1837 Allactaga sp.}

Material: two isolated teeth. Layer 4: one indet. Layer 5: one right lower m3. Description and discussion: this rodent group is poorly known in the Middle East (Shenbrot, 2009) and sometimes there is a size overlap between the species. In our sample, we only found two items attributed to Allactaga sp. on the basis of the complete lower $\mathrm{m} 3$, which presents a morphology with two inner folds and one outer fold; the other tooth is broken, which prevents any precise identification.

Habitat and distribution: in Iran four species are currently present: Allactaga elater, Allactaga euphratica, Allactaga firouzi and Allactaga hotsoni (Karami et al., 2008). The different species are morphologically very close and remain poorly studied. They are mainly found in steppe vegetation and semidesert areas (Shenbrot, 2009).

\section{Family Gliridae Thomas, 1897}

Genus Myomimus Ognev, 1924

Myomimus sp.

Material: five isolated teeth, Layer 5: five isolated teeth, one right lower m1, three right lower $\mathrm{m} 2$ and one left lower $\mathrm{m} 2$.

Description and discussion: the genus Myomimus is present in Iran with two species, Myomimus personatus and Myomimus setzeri (Firouz, 2005; Gerrie \& Kennerley, 2017; Karami et al., 2008; Kennerley \& Kryštufek, 2019). Regarding the remains found at Kaldar, the $\mathrm{m} 1$ is of a trapezium-like shape, and its anterior part tends to be narrower than the posterior part. The $\mathrm{m} 1$ has three roots, two in the anterior part and one in the posterior part. The $\mathrm{m} 2$ is subrectangular, and its occlusal pattern is simpler than in the $\mathrm{m} 1$. There are three roots in total, two in the anterior part and one in the posterior part (Kaya 
and Kaymakçı, 2018; Kryštufek and Vohralík, 2009). The two species are similar to one another and poorly studied. Consequently, we were unable to identify the Kaldar material precisely. Moreover, the reference collection of the Natural History Museum of London only houses Myomimus personatus specimens, which could therefore not be compared with Myomimus setzeri.

Habitat and distribution: these species are not well known as regards their distribution. They are mainly found in desert areas (Gerrie \& Kennerley, 2017; Kennerley \& Kryštufek, 2019).

Family Muridae Illiger, 1811 Genus Apodemus Kaup, 1829

Apodemus sp.

Material: 13 isolated teeth. Layer 1-3: two isolated teeth; one left lower $\mathrm{m} 1$ and one left lower m2; Layer 4: six isolated teeth; three left lower m1, two right lower $\mathrm{m} 1$ and one left upper M1. Layer 5: five isolated teeth; two left lower m1, one right lower $\mathrm{m} 1$, one right upper $\mathrm{M} 1$ and one $\mathrm{m} 2$.

Description and discussion: the first lower molar (m1) can be seen to present a low occlusal surface with six main cusps. The anterolabial and posterolabial cusps of $\mathrm{m} 1$ converge in an X-shape. The posterior cusp of $\mathrm{m} 1$ is low, rounded and well developed, with two or three secondary cusps in the labial part, and a mesial tubercle. We attribute the remains found in Kaldar Cave to Apodemus sp. because they present the traits characteristic of the genus Apodemus (Amori et al., 2016; Bogicevic et al., 2011; Knitlová and Horáček, 2017; Kryštufek and Vohralík, 2009; López-García, 2008).

Habitat and distribution: five Apodemus species are currently recognized in Iran: A. hyrcanicus, A. flavicollis, A. witherbyi, $A$. avicennicus and $A$. uralensis, all belonging to the Sylvaemus sub-genus (Jangjoo et al., 2011). Apodemus has a large distribution range extending from Great Britain across much of continental Europe to the Urals. It also extends east through Turkey to western Armenia, the Zagros Mountains of Iran and south to Syria, Lebanon and Israel. It inhabits a variety of woodland habitats (Amori et al., 2016).

\section{Genus Mus Linnaeus, 1758}

\section{Mus cf. musculus Linnaeus, 1758}

Material: three isolated teeth. Layer 4: one isolated tooth; one left upper M1. Layer 5: two isolated teeth; one indeterminate and one left lower $\mathrm{m} 1$.

Description and discussion: as in other murines, the first upper molar (M1) has three rows of tubercles: the first ( $t 1, \mathrm{t} 2, \mathrm{t} 3)$ and second ( $\mathrm{t} 4, \mathrm{t} 5$ and $\mathrm{t} 6)$ groups situated in the anterior part have three tubercles, and the third group (t7 and t9) has two tubercles (Darviche et al., 2006). In Iran (Kryštufek and Vohralík, 2009) both Mus musculus domesticus and Mus macedonicus may be found. 
The specimens from Kaldar Cave fit well with $M$. musculus as regards the upper M1 morphology: the lingual row of cusps (t1 and t4) is shifted posteriorly; cusp t7 is reduced to an enamel ridge; distal cusps t8 and t9 leave no space for a posterior cingulum or posterolabial cusp t12 (Siahsarvie and Darvish, 2008). The dental ends of the mesial and central cusps on $\mathrm{m} 1$ fuse early; the mesiolabial cusp is small. Upper molars normally have three roots each, one lingual and two labial, whereas lower molars are two-rooted (one anterior and one posterior) (Kryštufek and Vohralík, 2009). Despite these observations, bearing in mind the high intra-specific morphological variability, the low quantity of material and the bad state of preservation of some teeth (Fig. 2.13), we only attribute the Kaldar material to $M$. cf. musculus.

Habitat and distribution: Mus musculus is a commensal species, well distributed throughout the world: it is present over all the continents except Antarctica. It is found in a wide range of habitats but tends not to be found in forest and deserts. Mus musculus is ecologically highly opportunistic but a weak competitor; it can cope with aridity and can also expand into the desert (Kryštufek and Vohralík, 2009). It is also found in arid habitats along the border with Syria and Iraq, in desert landscapes and near the Euphrates River (Kryštufek \& Vohralík, 2009; Denys, 2017).

\subsection{Past landscape and climate at Kaldar Cave}

The small-mammal assemblages from Layers 4 and 5 of Kaldar Cave are dominated by the genus Microtus (60 individuals in Layer 4 and 79 in Layer 5), followed by Ellobius in Layer 4 (17 individuals) and Meriones cf. persicus (17 individuals in Layer 4 and 18 in Layer 5 ). These species indicate that the environment in the area was mainly composed of open dry and steppe areas, although we also found Apodemus sp. and Mus cf. musculus, which are related rather to a dense vegetation cover (including trees/bush). All the species identified at Kaldar Cave still occur in the area today.

Layers 1-3 do not yield enough material to draw palaeoclimatic inferences $(\mathrm{MNI}<30)$. For Layers 4 and 5 , the bioclimatic model shows similar results (Table 6). It should be pointed out that some species are not included in the BM data matrix, such as Myomimus (present in Layer 4) and Microtus guentheri (Layer 5), because their values did not appear in the $B M$ and could not be used in the analysis. The $B M$ based on the small mammals from Kaldar Cave suggests lower temperatures and lower precipitation than at present in both Layers 4 and 5 (Table 6). The MAT is around $6 \circ \mathrm{C}$ lower, and there is a higher temperature amplitude between maximum and minimum mean temperatures. This indicates that Layers 4 and 5 of Kaldar Cave were deposited during a colder period, which is not in agreement with the preliminary interpretations of Bazgir et al. (2017) suggesting a temperate "interstadial".

The climate in Khorramabad nowadays is warm an temperate. The average mean annual temperature is $16.90^{\circ} \mathrm{C}$, the maximum mean temperature occurs 
617 in July with $29.60^{\circ} \mathrm{C}$ and the minimum mean temperature is in January with $5^{\circ} \mathrm{C}$

618 (https://en.climate-data.org/asia/iran/lorestan/khorramabad-764550/). This

619 contrast with the climactic conditions inferred form the BM on Kaldar Cave with 620 lower temperatures and drier conditions.

621 Applying the habitat weighting method, our data show a palaeoenvironment 622 mainly composed of steppes in both levels. In Layer 4, grasslands are also well 623 represented, notably through the presence of Microtus guentheri. In Layer 5, 624 deserts are the second most represented habitat, thanks to the considerable presence of Myomimus sp. The proportion of rocky areas is also significant, indicated by the presence of Chionomys nivalis and Meriones cf. persicus (Figure 3).

There thus seems to be no major palaeoenvironmental or palaeoclimatic change that can explain the cultural shift between Layer 5 (Middle Palaeolithic) and 4 (Upper Palaeolithic). However, Layer 5 appears slightly colder and drier than Layer 4, with a higher proportion of desert habitats.

We can compare these results with previous studies carried out in Kaldar Cave using other palaeoenvironmental proxies. Charcoal analyses (Allué et al., 2018; Bazgir et al., 2017) indicate that there were active water sources or flows, with specific plant communities characteristic of open forest growing in cool and dry conditions (Allué et al., 2018). The presence of forested areas is also supported by the large mammals, with the presence of Sus scrofa, Capreolus sp. and Cervus elaphus (Bazgir et al., 2017). Several amphibian and squamate species have also been found (Bazgir et al., 2017): a toad (Bufo sp.), an agamid lizard (Agamidae indet.), a gecko (Gekkonidae indet.), a skink (Scincidae indet.), a lacertid (Lacertidae indet.), a glass lizard (Pseudopus sp.), a sand boa (Eryx sp.), possibly six types of colubrine snakes (Colubrinae indet.), a cobra (Elapidae indet.), and a viper (Viperidae indet.). Most of these taxa (Agamidae, Eryx and Elapidae) live in savannahs, steppes and deserts, with a way of life always linked with warm arid areas in rocky or sandy environments. Pseudopus lives in dry and bushy environments, sometimes in open woodlands, but avoids dense forest areas (Bazgir et al., 2017).

Our results based on small mammals, combined with previous studies of other proxies, thus suggest a mosaic landscape alternating between dry-steppe areas and wooded patches. Nowadays, the vegetation in the Zagros is a montane grassland-woodland characterised by steppe of grassland and herbs with occasional to fairly common trees. The principal local trees are deciduous oaks and junipers, with maples, walnut, almond and ash at middle elevations, and Pistacia and Olea in drier areas (Fiacconi and Hunt, 2015). Thus, the landscape during the Middle and Upper Pleistocene at Kaldar Cave was similar to that today, despite a colder climate.

\subsection{Kaldar Cave in the Middle Eastern context}


Kaldar Cave is situated in the Khorramabad Valley, which played a significant role in human adaptation and dispersal during the Quaternary. Some other caves close to Kaldar, such as Gilvaran, Ghamari and Gar Arjene rock shelter, have yielded Mousterian and Aurignacian occupations (Bazgir et al., 2014). Moreover, surveys in Kermanshah have also documented Middle and Upper Palaeolithic sites (Heydari-Guran and Ghasidian, 2020). None of them has given rise to small-mammal studies. However, Gilvaran Cave has been studied from a palaeoenvironmental point of view through charcoal analyses (Allué et al., 2018), showing a similar pattern to Kaldar, where Prunus is also present and indicates the presence of open forest areas. Similarly, other proxies such as pollens and charcoals have been analysed at Shanidar (Campana and Crabtree, 2019; Fiacconi and Hunt, 2015) and Gilvaran (Allué et al., 2018), indicating similar environmental conditions to Kaldar.

Other studies based on small mammals from the Middle East have been performed in Qesem Cave (Maul et al., 2015a; Smith et al., 2015), Hummal (Maul et al., 2015b), Azokh Cave (Fernández-Jalvo, 2016), Aghitu-3 Cave (Frahm, 2019; Kandel et al., 2017; Nishiaki and Akazawa, 2018), Nesher Ramla (Weissbrod and Zaidner, 2014), Amud Cave (Belmaker and Hovers, 2011), Dzudzuana Cave (Belmaker et al., 2016) and Karain Cave (Demirel et al., 2011). These studies did not use $H W$ or the $B M$ for their palaeoclimatic and palaeoenvironmental reconstructions, and the sites are not always contemporary with Kaldar, except Amud Cave (Belmaker and Hovers, 2011), Aghitu-3 (Djamali et al., 2008; Kandel et al., 2017) and Dzudzuana Cave (Belmaker et al., 2016) (Table 7).

Most of these studies highlight problems in identifying Middle Eastern rodent species, as faced in the present work. There are some studies of present-day taxonomy and systematics in Iran, Turkey, Israel, Jordan, Lebanon and Syria (Abi-said et al., 2014; Darvish et al., 2000; Haddadian Shad et al., 2014; Kopij and Liven-schulman, 2013; Obuch and Khaleghizadeh, 2012; Shehab et al., 2013), but these are mostly based on skull morphology and thus not applicable in archaeological or palaeontological contexts where the remains are broken. Very few studies provide descriptions of molars with comparative elements, allowing for the correct identification of fossil specimens. In this context, comparison with modern specimens from museum collections of genetically typed specimens is crucial to establish a correct taxonomic reference.

Palaeoenvironmental inferences have been drawn on the basis of smallmammal studies, as well as palynological and anthracological analyses. During the Upper Pleistocene, small-mammal compositions differ from one site to another (Belmaker et al., 2016; Kandel et al., 2017) (Table 8), probably because the sites are not exactly contemporaneous and are likely to belong to different eco-regions. It is noteworthy that the genera Microtus, Chionomys, Cricetulus, Mesocricetus, Ellobius and Allactaga are represented in all the sites, allowing us to reconstruct the species communities of this region. Kaldar is the most diverse site in terms of small-mammal species. 
We applied the habitat weighting method at other Middle Eastern sites where small-mammal studies have been performed, namely Aghitu-3 and Dzudzuana Cave, but these are located in other eco-regions (Figure 1a). Aghitu-3 is located in Armenia, at an elevation of $1601 \mathrm{~m}$ a.s.l. and the current climate is continental with considerable seasonality in temperature. Dzudzuana Cave is located in Georgia, at an elevation of $560 \mathrm{~m}$ a.s.l., and the current climate is warm and temperate. The estimations obtained with the habitat weighting method (Figure 4) show similar environmental conditions between Kaldar Cave and Aghitu-3, where the landscape is dominated by steppe (indicated by the presence of Ellobius lutescens, Mesocricetus brandti, Cricetulus migratorius and Allactaga), with a relatively high percentage of grassland and forests.

To ascertain the palaeoclimatic conditions, we calculated and directly compared our results with Aghitu-3 and Dzudzuana Cave using the bioclimatic method (Table 9). The results obtained for Aghitu-3 show higher temperatures and precipitation than at present, whereas Dzudzuana Cave shows the same pattern as Kaldar Cave, with drier conditions and lower temperatures than today. For Amud Cave, it was not possible to calculate $H W$ and $B M$, but data from the literature (Belmaker and Hovers, 2011) indicate a grassland environment similar to the one that we reconstructed at Dzudzuana Cave.

\section{Conclusions}

This work represents the first study of a Late Pleistocene rodent assemblage from the Middle East with palaeoenvironmental and palaeoclimatic reconstructions, using and adapting the habitat weighting method and the bioclimatic model to this area. We identified 1112 rodent remains, corresponding to a minimum number of 264 individuals. The rodent assemblage is composed of 13 taxa: six arvicoline (Microtus socialis, Microtus irani, Microtus guentheri, Chionomys nivalis, Ellobius fuscocapillus and Ellobius lutescens), two cricetine (Cricetulus migratorius and Mesocricetus brandti), one glirid (Myomimus sp.), one gerbilline (Meriones cf. persicus), one dipodid (Allactaga sp.) and two murine species (Apodemus sp. and Mus cf. musculus). Augmenting the preliminary analysis of the material (Bazgir et al., 2017), new species were identified, such as Microtus socialis, Microtus irani, Microtus guentheri, Ellobius fuscocapillus and Meriones cf. persicus. We also reconsidered the identification of Ellobius talpinus, Calomyscus sp. and Dryomys cf. nitedula, based on modern specimens from museum collections and measurements; this is why they do not appear in the new faunal list of Kaldar Cave.

Given the scarcity of studies in this biogeographical region, we encountered some difficulties in the identification of species, which could slightly affect the palaeoenvironmental and palaeoclimatic interpretations. In order to counter these potential errors, further studies of small mammals in this region are 
necessary, as well as research on discriminant characters in molars, using reference collections including genetically typed specimens.

The palaeoecological analysis of the rodents from Kaldar Cave revealed lower temperatures and lower precipitation than present-day conditions, and an environment mainly composed of dry steppes with patches of forested areas. The results obtained are supported by palynological, anthracological and largemammal studies. At a broader geographical scale, colder conditions were also inferred at Dzudzuana Cave. The genera Microtus, Chionomys, Cricetulus, Mesocricetus, Ellobius and Allactaga are present at all the Middle East sites (Aghitu-3, Dzudzuana and Amud) during the Upper Pleistocene, that have yielded small mammals, allowing us to reconstruct the rodent communities of the area.

Considering all the results from Kaldar Cave and other contemporaneous sites, we can conclude that both Neanderthals and $\mathrm{AMH}$ lived in dry steppes with patches of forested areas, without major environmental changes occurring between the Middle and the Late Palaeolithic. Climatic shifts during the MIS 4-3 transition were of a magnitude that did not have a major impact on small mammals in the region, suggesting that climate change may not have had the hypothesized effect on the Neanderthal extinction in the Levant.

Acknowledgments: I. Rey-Rodriguez is the beneficiary of a PhD scholarship funded by the Erasmus Mundus Program (IDQP). J.M. López-García was supported by a Ramón y Cajal contract (RYC-2016-19386) with financial sponsorship from the Spanish Ministry of Science, Innovation and Universities. M. Fernández-García is the beneficiary of a PEJ grant (PEJ2018-005222-P) funded by the Spanish National Youth Guarantee System and the European Social Fund. This work was developed within the framework of the projects 2017SGR859, 2017SGR840 and 2017SGR1040 (AGAUR, Generalitat de Catalunya), and 2018PFRURVB291 (Univ. Rovira i Virigli). We thank the head of the Research Institute of Cultural Heritage and Tourism (RICHT) (Dr. B. Omrani) and the head of the Iranian Center for Archaeological Research (ICAR) (Dr. R. Shirazi) for providing us with the necessary support and permissions in studying the materials. We thank the head of the Lorestan Cultural Heritage, Handicraft and Tourism Organization (Mr. A. Ghasemi) for all his support. We also thank the head of International Collaboration and Ties of the RICHT (Mrs. M. Kholghi) for all her cooperation and help. B. Bazgir received his PhD scholarship from the Fundación Atapuerca, for which he is grateful. Laxmi Tumung received her PhD scholarship from the Erasmus Mundus Programme (IDQP). We would like to thank Roberto Portela Miguez, Senior Curator in Charge of Mammals, for his help with the reference collection in the Natural History Museum of London. We would like to thank Rupert Glasgow for reviewing the English language of the manuscript. We also want to thank to the Editor Prof. José S. Carrion and the two anonymous reviewers for their 
comments and suggestions that strongly improve the final version of the manuscript.

\section{References}

Abi-Said, M.R., Shehab, A.H., Amr, Z.S., 2014. Diet of the Barn Owl. Jordan Journal of Biological Sciences, Vol. 7, № 2, 109-112.

Allué, E., Expósito, I., Tumung, L., Ollé, A., Bazgir, B., 2018. Early evidence of Prunus and Prunus cf. amygdalus from Palaeolithic sites in the Khorramabad Valley, western Iran. Comptes Rendus Palevol 17, 335-345. https://doi.org/10.1016/j.crpv.2018.01.001

Amori, G. 1999. Chionomys nivalis. In: A. J. Mitchell-Jones, G. Amori, W. Bogdanowicz, B. Kryštufek, P. J. H. Reijnders, F. Spitzenberger, M. Stubbe, J. B. M. Thissen, V. Vohralík and J. Zima (eds), The Atlas of European Mammals, Academi Press, London, UK

Amori, G., Hutterer, R., Kryštufek, B., Yigit, N., Mitsain, G. \& Palomo, L.J., 2016. Apodemus flavicollis. The IUCN Red List of Threatened Species 2016: e.T1892A115058023.

8235.

https://doi.org/http://dx.doi.org/10.2305/IUCN.UK.2016-

3.RLTS.T1892A22423256.en

Amr, A., 2015. Microtus guentheri, The IUCN Red List of Threatened Species 2016: e.T13463A22349143.

Andrews, P., 1990. Owls, Caves and Fossils, Owls, Caves and Fossils. https://doi.org/10.2307/3889096

Andrews, P., 2006. Taphonomic effects of faunal impoverishment and faunal mixing. Palaeogeography, Palaeoclimatology, Palaeoecology 241, 572-589. https://doi.org/10.1016/j.palaeo.2006.04.012

Aşan Baydemir, N., Duman, L., 2009. Molar patterns in Microtus guentheri (Danford and Alston, 1880) (Mammalia: Rodentia) from Kirikkale province. Journal of Applied Biological Sciences 3, 47-54.

Bazgir, B., Ollé, A., Tumung, L., Becerra-Valdivia, L., Douka, K., Higham, T., Van Der Made, J., Picin, A., Saladié, P., López-Garciá, J.M., Blain, H.-A., Allué, E., Fernández-Garciá, M., Rey-Rodríguez, I., Arceredillo, D., Bahrololoumi, F., Azimi, M., Otte, M., Carbonell, E., 2017. Understanding the emergence of modern humans and the disappearance of Neanderthals: Insights from Kaldar Cave (Khorramabad Valley, Western Iran). Scientific Reports 7. https://doi.org/10.1038/srep43460

Bazgir, B., Otte, M., Tumung, L., Ollé, A., Deo, S.G., Joglekar, P., López-García, J.M., Picin, A., Davoudi, D., van der Made, J., 2014. Test excavations and initial results at the middle and upper paleolithic sites of Gilvaran, Kaldar, Ghamari caves and Gar Arjene Rockshelter, Khorramabad Valley, western Iran. Comptes Rendus - Palevol 13, 511-525. https://doi.org/10.1016/j.crpv.2014.01.005

Becerra-Valdivia, L., Douka, K., Comeskey, D., Bazgir, B., Conard, N.J., Marean, C.W., Ollé, A., Otte, M., Tumung, L., Zeidi, M., Higham, T.F.G., 2017. 
Chronometric investigations of the Middle to Upper Paleolithic transition in the Zagros Mountains using AMS radiocarbon dating and Bayesian age modelling. Journal of Human Evolution 109, 57-69. https://doi.org/10.1016/j.jhevol.2017.05.011

Belmaker, M., Bar-Yosef, O., Belfer-Cohen, A., Meshveliani, T., Jakeli, N., 2016. The environment in the Caucasus in the Upper Paleolithic (Late Pleistocene): Evidence from the small mammals from Dzudzuana cave, Georgia. Quaternary International 425, 4-15. https://doi.org/10.1016/j.quaint.2016.06.022

Belmaker, M., Hovers, E., 2011. Ecological change and the extinction of the Levantine Neanderthals: Implications from a diachronic study of micromammals from Amud Cave, Israel. Quaternary Science Reviews 30, 3196-3209. https://doi.org/10.1016/j.quascirev.2011.08.001

Blain, H.-A., Bailon, S., Cuenca-Bescós, G., 2008. The Early-Middle Pleistocene palaeoenvironmental change based on the squamate reptile and amphibian proxies at the Gran Dolina site, Atapuerca, Spain. Palaeogeography, Palaeoclimatology, Palaeoecology 261, 177-192. https://doi.org/10.1016/j.palaeo.2008.01.015

Bogicevic, K., Nenadic, D., Mihailovic, D., Lazarevic, Z., Milivojevic, J., 2011. Late Pleistocene rodents (Mammalia: Rodentia) from the Baranica cave near Knjaževac (eastern Serbia): Systematics and palaeoecology. Rivista Italiana di Paleontologia e Stratigrafia, Vol. 117, №2, 331-346.

Campana, D. V., Crabtree, P., 2019. Evidence for skinning and craft activities from the Middle Paleolithic of Shanidar Cave, Iraq. Journal of Archaeological Science: Reports 25, 7-14. https://doi.org/10.1016/j.jasrep.2019.03.024

Corbet, G.B., 1978. The Mammals of the Palearctic Region: A Taxonomic Review. London, Brit. Mus.(Nat. Hist.). Cornell Univ. Press. 117- 118.

Corbet, G.B. and Hill, J.E., 1991. A World List of Mammalian Species. $3^{\text {rd }}$ ed. London, UK: British Museum (Natural History).

Coşkun, Y., 2016. Review of unique odd chromosome-numbered underground rodent species of the Palearctic region: Ellobius Lutescens Thomas 1897 (Rodentia: Cricetidae). Turkish Journal of Zoology 40, 831-841. https://doi.org/10.3906/zoo-1509-53

Coşkun, Y., 1999. Morphological characteristics of Meriones tristrami Thomas, 1892 (Rodentia: Gerbillinae) from Diyarbakır, Turkey. Turk. J. Zool 23, 345355.

Coşkun,Y., 1997. Ellobius lutescens Thomas, 1897 (Rodentia: Cricetidae) Turk. J. of Zoology. 21, 349-354.

Darlington, P.J., 1957. Zoogeography: The Geographical Distribution of Animals. New York, NY, USA: John Wiley and Sons.

Darviche, D., Orth, A., Michaux, J., 2006. Mus spretus et M. musculus (Rodentia, Mammalia) en zone méditerranéenne: Différenciation biométrique et morphologique: Application à des fossiles marocains pléistocènes. Mammalia 70, 90-97. https://doi.org/10.1515/MAMM.2006.010

Darvish, J., Mohammadi, Z., Mahmoudi, A., Siahsarvie, R., 2014. Faunistic and 
taxonomic study of Rodents from northwestern Iran. Iranian Journal of Animal Biosystematics (IJAB) 10, 119-136.

Darvish, J., 2011. Morphological comparison of fourteen species of the genus Meriones Illiger, 1811 (Rodentia: Gerbillinae) from Asia and North Africa. Iranian Journal of Animal Biosystematics 7, 49-74.

Darvish, J., Ghiyasi, R., Khosravi, M., 2000. Recognition of rodents of Robat Sharaf pellets owl by morphological and neontological studies. Journal of Sciences 12.

Denys, C., 2017. Subfamily Deomyinae, Gerbillinae, Leimacomyinae, Lophiomyinae species accounts. Pp. 598-650. in : Wilson, D.E., Lacher, T.E., Jr. \& Mittermeier, R.A. eds. Handbook of the Mammals of the World. Vol.7. Rodents II. Lynx Edicions, Barcelona.

Demirel, A., Andrews, P., Yalçinkaya, I., Ersoy, A., 2011. The taphonomy and palaeoenvironmental implications of the small mammals from Karain Cave, Turkey. Journal of Archaeological Science 38, 3048-3059. https://doi.org/10.1016/j.jas.2011.07.003

Dianat, M., Darvish, J., Cornette, R., Aliabadian, M., Nicolas, V., 2017. Evolutionary history of the Persian Jird, Meriones persicus, based on genetics, species distribution modelling and morphometric data. Journal of Zoological Systematics and Evolutionary Research 55, 29-45. https://doi.org/10.1111/jzs.12145

Djamali, M., de Beaulieu, J.L., Shah-hosseini, M., Andrieu-Ponel, V., Ponel, P., Amini, A., Akhani, H., Leroy, S.A.G., Stevens, L., Lahijani, H., Brewer, S., 2008. A late Pleistocene long pollen record from Lake Urmia, NW Iran. Quaternary Research 69, 413-420. https://doi.org/10.1016/j.yqres.2008.03.004

Ellerman, J.R, and Morrison-Scott, T.C.S., 1951. Checklist of Palearctic and Indian Mammals, 1780 to 1946. Brit. Mus. Nat. Hist. London, 1-810.

Evans, E.M.N., Van Couvering, J.A.H., Andrews, P., 1981. Palaeoecology of Miocene sites in western Kenya. J. Hum. Evol. 10, 99-116.

Fernández-Jalvo Y., King T., Yepiskoposyan L. \& Andrews P. (eds.), 2016a. Azokh Cave and the Transcaucasian Corridor, Vertebrate Paleobiology and Paleoanthropology Series, Springer

Fernández-Jalvo, Y., Andrews, P., Denys, C., Sesé, C., Stoetzel, E., MarinMonfort, D., Pesquero, D., 2016b. Taphonomy for taxonomists: Implications of predation in small mammal studies. Quaternary Science Reviews 139, 138157. https://doi.org/10.1016/j.quascirev.2016.03.016

Fiacconi, M., Hunt, C.O., 2015. Pollen taphonomy at Shanidar Cave (Kurdish Iraq): An initial evaluation. Review of Palaeobotany and Palynology 223, 87-93. https://doi.org/10.1016/j.revpalbo.2015.09.003

Firouz, E., 2005. The complete fauna of Iran. Ed. I.B.Tauris \& Co Ltd

Frahm, E., 2019. Upper Palaeolithic Settlement and Mobility in the Armenian Highlands: Agent-Based Modeling, Obsidian Sourcing, and Lithic Analysis at Aghitu-3 Cave.

Gerrie, R., Kennerley, R., 2017. Myomimus personatus. The IUCN Red List of 
Gharkheloo, M., Kivanç, E., 2003, A study on the morphology, karyology and distribution of Ellobius Fischer, 1814 (Mammalia: Rodentia) in Iran. Turkish Journal of Zoology 27(4):281-292

Golenishchev, F.,Malikov, V., Nazari, F., Vaziri, A.,Sablina, O., Polyakov, A., 2002. New species of vole of "guentheri "group (Rodentia, Arvicolinae, Microtus) from Iran. Russia Journal of Theriology 1 (2), 117-123

Golenishchev, F., Malikov, V., Petrova, T., Bodrov, S., Abramson, N., 2019. subgenus Microtus (Rodentia, Cricetidae). Mammalian Biology 94, 98-105. https://doi.org/10.1016/j.mambio.2018.06.007

Habibi, K. 2004. Mammals of Afghanistan. Zoo Outreach Organisation/USFWS, Coimbatore, India.

Haddadian Shad, H., Darvish, J., Mohammadian, T., Mahmoudi, A., Alaie Kakhki, N., Ghanbarifardi, M., Molavi, F., Barani-Beiranvand, H., 2014. Preliminary study of rodents using pellets of predatory birds in Iran. Iranian Journal of Animal Biosystematics 10, 36-50.

Hassinger, J.D., 1973. A survey of the mammals of Afghanistan: Resulting from the 1965 Street Expedition (Excluding Bats). Fieldiana Zoology, Vol. 60. Chicago, IL, USA: Field Museum of Natural History.

Hernández Fernández, M., 2001. Bioclimatic discriminant capacity of terrestrial mammal faunas. Global Ecology and Biogeography 10, 189-204. https://doi.org/10.1046/j.1466-822x.2001.00218.x

Hernandez Fernández, M., Peláez-Campomanes, P., 2003. The bioclimatic model: A method of palaeoclimatic qualitative inference based on mammal associations. Global Ecology and Biogeography 12, 507-517. https://doi.org/10.1046/j.1466-822X.2003.00057.x

Hernández Fernández, M., Álvarez Sierra, M.Á., Peláez-Campomanes, P., 2007. Bioclimatic analysis of rodent palaeofaunas reveals severe climatic changes in Southwestern Europe during the Plio-Pleistocene. Palaeogeography, Palaeoclimatology, Palaeoecology 251, 500-526. https://doi.org/10.1016/j.palaeo.2007.04.015

Heydari-Guran, S., Ghasidian, E., 2020. Late Pleistocene hominin settlement patterns and population dynamics in the Zagros Mountains: Kermanshah region. Archaeological Research in Asia 21, 100161. https://doi.org/10.1016/j.ara.2019.100161

Hinton, M.A.C., 1926. Monograph of the Voles and Lemmings (Microtinae) Living and Extinct. London: British Museum (Natural History). Vol.1. 488 p.

Jangjoo, M., J.Darvish \& J. D. Vign 2011. Application of outline analysis on fossil and modern specimens of Apodemus. - Iranian J. Anim. Biosystem., 7 (2): 143155.

Kandel, A.W., Gasparyan, B., Allué, E., Bigga, G., Bruch, A.A., Cullen, V.L., 
Frahm, E., Ghukasyan, R., Gruwier, B., Jabbour, F., Miller, C.E., Taller, A., Vardazaryan, V., Vasilyan, D., Weissbrod, L., 2017. The earliest evidence for Upper Paleolithic occupation in the Armenian Highlands at Aghitu-3 Cave. Journal of Human Evolution 110, 37-68. https://doi.org/10.1016/j.jhevol.2017.05.010

Karami, M., Hutterer, R., Benda, P., Siahsarvie, R., Kryštufek, B., 2008. Annotated check-list of the mammals of Iran. Lynx (Praha) 39, 63-102.

Kaya, F., Kaymakçı, N., 2018. Systematics and dental microwear of the late Miocene Gliridae (Rodentia, Mammalia) from Hayranlı, Anatolia: Implications for paleoecology and paleobiodiversity. Palaeontologia Electronica 16. https://doi.org/10.26879/385

Kennerley, R., Kryštufek, B., 2019. Myomimus setzeri,. The IUCN Red List of Threatened Species 2019: e.T14089A22222049. 8235. https://doi.org/http://dx.doi.org/10.2305/IUCN.UK.2019-

1.RLTS.T14089A22222049.en

Knitlová, M., Horáček, I., 2017. Late Pleistocene-Holocene paleobiogeography of the genus Apodemus in Central Europe. PLoS ONE 12, 1-23. https://doi.org/10.1371/journal.pone.0173668

Kopij, G., Liven-Schulman, I., 2013. Zoology in the Middle East Diet of the Lesser Kestrel, Falco naumanni, in Israel 7140. https://doi.org/10.1080/09397140.2012.10648914

Kretzoi, M., 1969. Skizze einer Arvicoliden Phylogenie -Stand 1969 // Vertebrata Hungarica. Vol.11. No.1-2. P.155-193.

Kryštufek, B., Bukhnikashvili, A., Sozen, M., Isfendiyaroglu, S., 2017. Cricetulus migratorius. The IUCN Red List of Threatened Species 2016: e.T5528A115073390

8235. https://doi.org/http://dx.doi.org/10.2305/IUCN.UK.2016-

3.RLTS.T5528A22391440.en

Kryštufek, B., Yigit, N., Amori, G., 2015. Mesocricetus brandti, Brandt' s Hamster. The IUCN Red List of Threatened Species 2008: e.T13220A3421550. 8235. https://doi.org/http://dx.doi.org/10.2305/IUCN.UK.2008.RLTS.T13220A3421550. en

Kryštufek, B. , Shenbrot, G., 2016. Ellobius lutescens, Transcaucasian Mole Vole. The IUCN Red List of Threatened Species 2016: e.T7655A22340006. 8235. https://doi.org/http://dx.doi.org/10.2305/IUCN.UK.20162.RLTS.T7655A22340006.en

Krystufek, B., 2017. Chionomys nivalis, European Snow Vole. The IUCN Red List of Threatened Species 2016: e.T4659A115069366 8235. https://doi.org/http://dx.doi.org/10.2305/IUCN.UK.2016-

3.RLTS.T4659A22379147.en

Kryštufek, B., Kefelioğlu, H., 2001. Redescription and species limits of Microtus irani Thomas, 1921, and description of a new social vole from Turkey (Mammalia: Arvicolinao). 
Kryštufek, B., Vohralík, V., 2009. Mammals of Turkey and Cyprus, Rodentia II: Cricetinae, Muridae, Spalacidae, Calomyscidae, Capromyidae, Hystricidae, Castoridae. https://doi.org/10.1644/10-MAMM-R-221.1

Lay, D.M., 1967. A Study of the Mammals of Iran, Resulting from the Street Expedition of 1962-63. Fieldiana Zool., 54: 168-171.

López-García, J.M., 2011. Los micromamíferos del Pleistoceno superior de la Península Ibérica: Evolución de la diversidad taxonómica y cambios paleoambientales y paleoclimáticos. Editorial Académica Española

López-García, J.M., Blain, H.-A., Cuenca-Bescós, G., Alonso, C., Alonso, S., Vaquero, M., 2011. Small vertebrates (Amphibia, Squamata, Mammalia) from the late Pleistocene-Holocene of the Valdavara-1 cave (Galicia, northwestern Spain). Geobios 44, 253-269. https://doi.org/10.1016/j.geobios.2010.10.001

Maul, L.C., Bruch, A.A., Smith, K.T., Shenbrot, G., Barkai, R., Gopher, A., 2015a. Palaeoecological and biostratigraphical implications of the microvertebrates of Qesem Cave in Israel. Quaternary International. https://doi.org/10.1016/.q.quaint.2015.04.032

Maul, L.C., Smith, K.T., Shenbrot, G., Bruch, A.A., Wegmüller, F., Le Tensorer, J.M., 2015b. Microvertebrates from unit G/layer 17 of the archaeological site of Hummal (El Kowm, Central Syria): Preliminary results. Anthropologie (France) 119, 676-686. https://doi.org/10.1016/j.anthro.2015.10.010

Miller, G.S., 1896. Genera and subgenera of voles and lemmings// North American Fauna. Vol.12. P.1-85.

Molur, S. \& Sozen, M., 2016. Meriones persicus, Persian Jird. The IUCN Red List of Threatened Species 2016: e.T13166A22433231. 8235. https://doi.org/http://dx.doi.org/10.2305/IUCN.UK.2016-

2.RLTS.T13166A22433231.en

Moradi Gharkheloo, M., 2003. A Study on the Morphology , Karyology and Distribution of Ellobius Fischer, 1814 ( Mammalia: Rodentia) in Iran. Turkish Journal of Zoology 27, 281-292.

Neumann, K., Yiğit, N., Fritzsche, P., Çolak, E., Feoktistova, N., Surov, A., Michaux, J., 2017. Genetic structure of the Turkish hamster (Mesocricetus brandti). Mammalian Biology

86 ,

84-91. https://doi.org/10.1016/j.mambio.2017.06.004

Nishiaki, Y., Akazawa, T., 2018. The Middle and Upper Paleolithic Archeology of the Levant and Beyond. Replacement of Neanderthals by Modern Humans Series 35-47. https://doi.org/10.1007/978-981-10-6826-3_3

Nowak, R.M., 1999. Walker's Mammals of the World. 6th ed. Baltimore, MD, USA: The Johns Hopkins University Press.

Obuch, J., Khaleghizadeh, A., 2012. Spatial Variation in the Diet of the Barn Owl Tyto alba in Iran 6, 103-116.

Osborn, D.J., 1962. Rodents of subfamily Microtinae from Turkey. J. Mammalia, 43: 515-529.

Rey-Rodríguez, I., Stoetzel, E., López-García, J.M., Denys, C., 2019. Implications of modern Barn owls pellets analysis for archaeological studies in 
the Middle East. Journal of Archaeological Science 111, 105029. https://doi.org/10.1016/J.JAS.2019.105029

Roberts, T.J., 1977. The Mammals of Pakistan. London, UK: Ernst Benn Ltd. Rusin, M., 2017. Ellobius talpinus, Northern Mole Vole. The IUCN Red List of https://doi.org/http://dx.doi.org/10.2305/IUCN.UK.2016-

3.RLTS.T7656A22339917.en

Sándor, A.D., 2018. Rediscovered after half a century: A new record of the grey dwarf hamster, Cricetulus migratorius (Mammalia: Cricetidae), in Romania. Turkish Journal of Zoology 42, 495-498. https://doi.org/10.3906/zoo-1712-15 Shehab, A., Daoud, A., Kock, D., Amr, Z., 2013. Zoology in the Middle East Small mammals recovered from owl pellets from 7140. https://doi.org/10.1080/09397140.2004.10638061

Shenbrot, G., Kryštufek, B., Molur, S., 2016. Ellobius fuscocapillus , Southern Mole Vole. The IUCN Red List of Threatened Species 2016: e.T7654A22339730.

8235. https://doi.org/http://dx.doi.org/10.2305/IUCN.UK.2016-

\section{RLTS.T7654A22339730.en}

Shenbrot, G., 2009. On the conspecifity of Allactaga hotsoni Thomas, 1920 and Allactaga firouzi Womochel, 1978 (Rodentia: Dipodoidea). Mammalia 73, 231237. https://doi.org/10.1515/MAMM.2009.043

Shenbrot, G.I. and Krasnov, B.R. 2005. An Atlas of the Geographic Distribution of the Arvicoline Rodents of the World (Rodentia, Muridae: Arvicolinae). Pensoft Publishers, Sofia.

Siahsarvie, R., Darvish, J., 2008. Geometric morphometric analysis of Iranian wood mice of the genus Apodemus (Rodentia, Muridae). Mammalia 72, 109-

Smith, K.T., Christian, L., Flemming, F., Barkai, R., Gopher, A., 2016. The microvertebrates of Qesem Cave: A comparison of the two concentrations. Quaternary International 1-13. https://doi.org/10.1016/j.quaint.2015.04.047

Souttou, K., Denys, C., 2012. Small Mammal Bone Modifications in BlackShouldered Kite Elanus caeruleus Pellets from Algeria: Implications for Archaeological Sites. Journal of Taphonomy 10, 1-19.

Stoetzel, E., Cornette, R., Lalis, A., Nicolas, V., Cucchi, T., Denys, C., 2017. Systematics and evolution of the Meriones shawii/grandis complex (Rodentia, Gerbillinae) during the Late Quaternary in northwestern Africa: Exploring the role of environmental and anthropogenic changes. Quaternary Science Reviews 164, 199-216. https://doi.org/10.1016/j.quascirev.2017.04.002

Tesakov, A.S., 2016. Early Middle Pleistocene Ellobius ( Rodentia, Cricetidae, Arvicolinae ) from Armenia. Russian J. Theriol. 15 (2): 151-158.

Thomas, O., 1905. Ellobius woosnami. Abstr. Proc. Zool. Soc. 23; Proc. Zool. Soc. 526 London.

Tsytsulina, K., Kryštufek, B., Yigit, N., Bukhnikashvili, A., Shenbrot, G., 2017. Microtus socialis , Social. The IUCN Red List of Threatened Species 2016: 
e.T13458A115114745. 8235.https://doi.org/http://dx.doi.org/10.2305/IUCN.UK.20163.RLTS.T13458A22348936.en Walker, E.P., 1964. Mammals of the World. Vol. 2. Baltimore, MD,USA: The Johns Hopkins Press.

1103 Weissbrod, L., Zaidner, Y., 2014. Taphonomy and paleoecological implications of 1104 fossorial microvertebrates at the Middle Paleolithic open-air site of Nesher 1105 Ramla, Israel. Quaternary International 331, 115-127. 1106 https://doi.org/10.1016/j.quaint.2013.05.044

1107 Wilson, D.E. and Reeder, D.M., 2005. Mammal Species of the World. 1108 Washington, DC, USA: Smithsonian Institution Scholarly Press. 


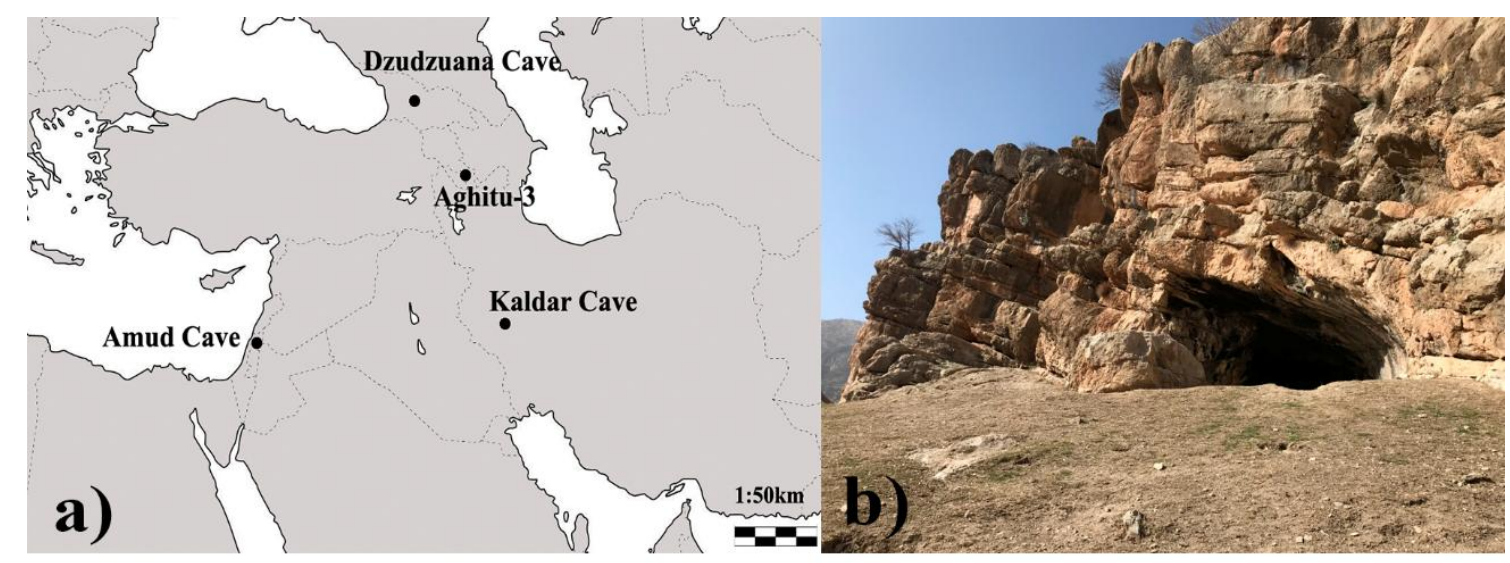

c)

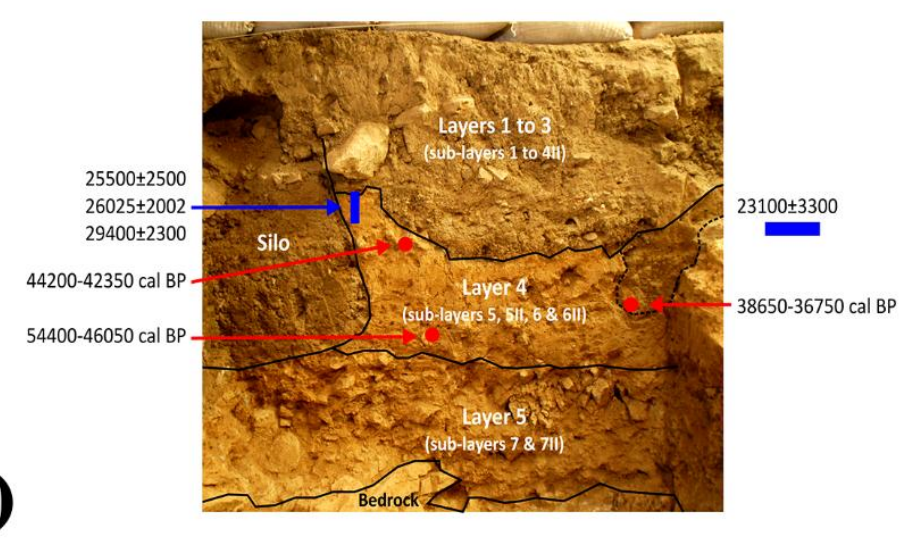

Figure 1: a) Locations of the Late Pleistocene sites with rodent studies in the Middle East, including Kaldar Cave. b) General view of the entrance to Kaldar Cave. c) Stratigraphy of the eastern section of Kaldar Cave, including the location and results of the dated samples, from A. Ollé and B. Bazgir (Bazgir et al., 2017). 


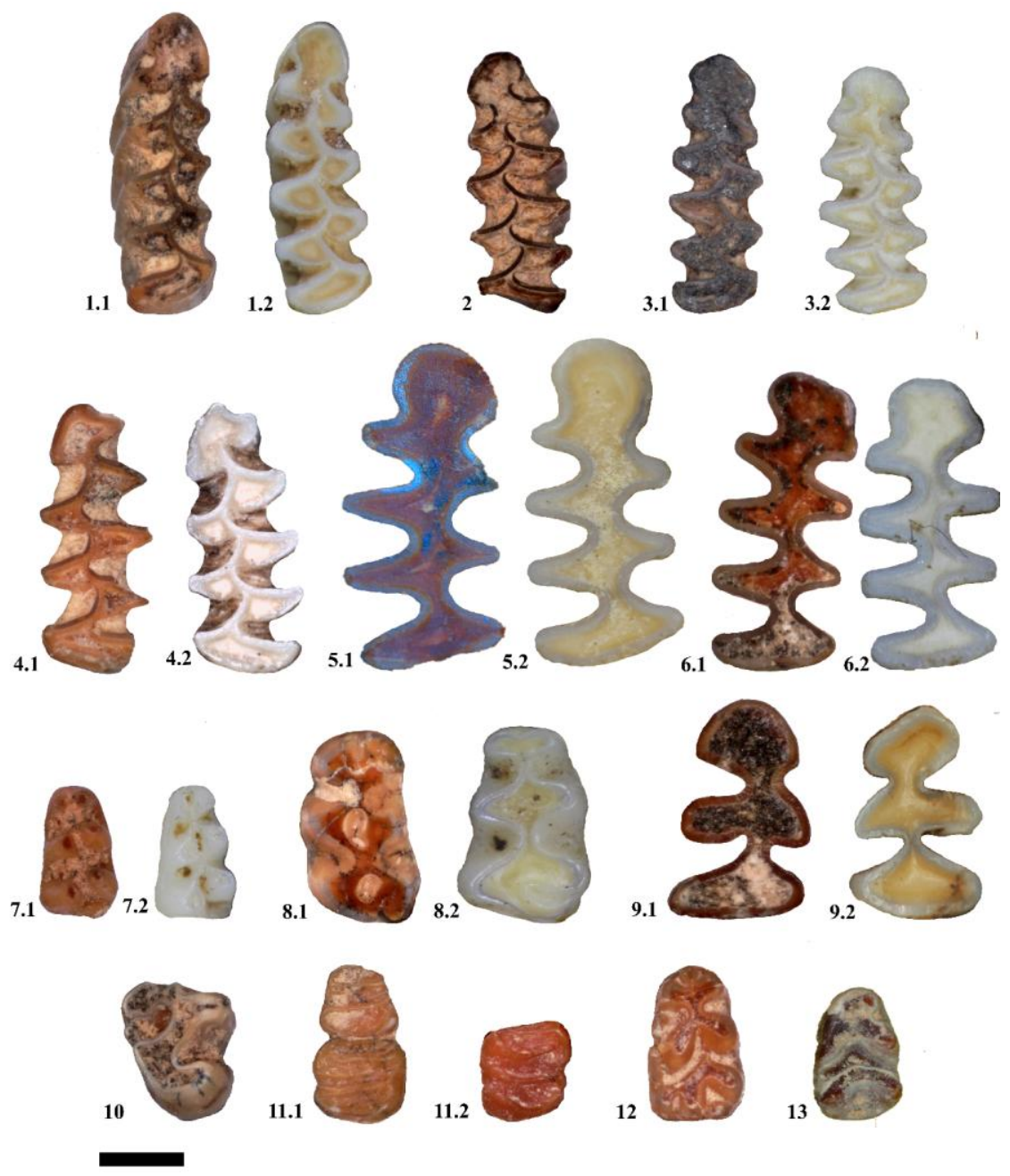

Figure 2: Some rodent species identified at Kaldar Cave in comparison with equivalent (analogue) modern specimens from the NHM of London. 1) Microtus irani: 1.1-Kaldar Cave, 2014, Layer 5 (sub-layer 7II), E7, 150-156, right lower m1, number 447. 1.2-modern, NHM205207, Iran (Shiraz), right lower m1; 2) Microtus guentheri: 2.1-Kaldar Cave, 2014, Layers 1-3 (sub-layer 4II), F6, 97-107, left lower m1, number 17; 3) Microtus socialis: 3.1Kaldar Cave, 2014, Layer 4 (sub-layer 5II), F7, 115-118, right lower m1, number 106. 3.2modern, NHM631799, Turkey (Amasya); 4) Chionomys nivalis: 4.1-Kaldar Cave, 2014, Layer 4 (sub-layer 5), E6, 94-104, left lower m1, number 542. 4.2-modern, NHM71820, Syria, left lower m1; 5) Ellobius fuscocapillus: 5.1-Kaldar Cave, 2014, Layer 4 (sub-layer 5II), E6, 125130, right lower m1, number 157. 5.2-modern, NHM86101513, Afghanistan, right lower m1; 6) Ellobius lutescens: 6.1-Kaldar Cave, 2014, Layer 5 (sub-layer 7II), F6, 130-140, right lower $\mathrm{m1}$, number 319. 6.2-NMH916416, Turkey, right lower $\mathrm{m} 1$; 7) Cricetulus migratorius: 7.1Kaldar Cave, 2014, Layer 4 (sub-layer 5II), E6, 135-140, left lower m1, number 259. 7.2modern, NHM773029, Iran, right lower m1; 8) Mesocricetus brandti: 8.1-Kaldar Cave, 2014, Layer 5 (sub-layer 7II), F6, 135-145, left upper M1, number 549. 8.2- modern, NHM193461226, Caucasus, left upper M1; 9) Meriones cf. persicus: 9.1-Kaldar Cave, 2014, Layer 5 (sub-layer 7II), F6, 156-166, left lower m1, number 551. 9.2-modern, NHM510434, Iran, left lower m1; 10) Allactaga sp.: 10.1-Kaldar Cave, 2014, Layer 5 (sub-layer 7II), E7, 141-147, right lower m3, number 203; 11) Myomimus sp.: 11.1- Kaldar Cave, 2014, Layer 5 (sub-layer 7II), E7, 141147, left lower $\mathrm{m} 1$ and $\mathrm{m} 2$. 11.2-modern, Myomimus personatus, NHM67623, Turkey, left lower mandible; 12) Apodemus sp.: 12.1-Kaldar Cave, 2014, Layer 4 (sub-layer 5), E6, 94104, right $\mathrm{m} 1$ and $\mathrm{m} 2$, number 547; 13) Mus cf. musculus: 13.1-Kaldar Cave, 2014, Layer 5 (sub-layer 7II), 166-174, left lower m1, number 495. Scale $1 \mathrm{~mm}$. 


\section{Kaldar Cave}

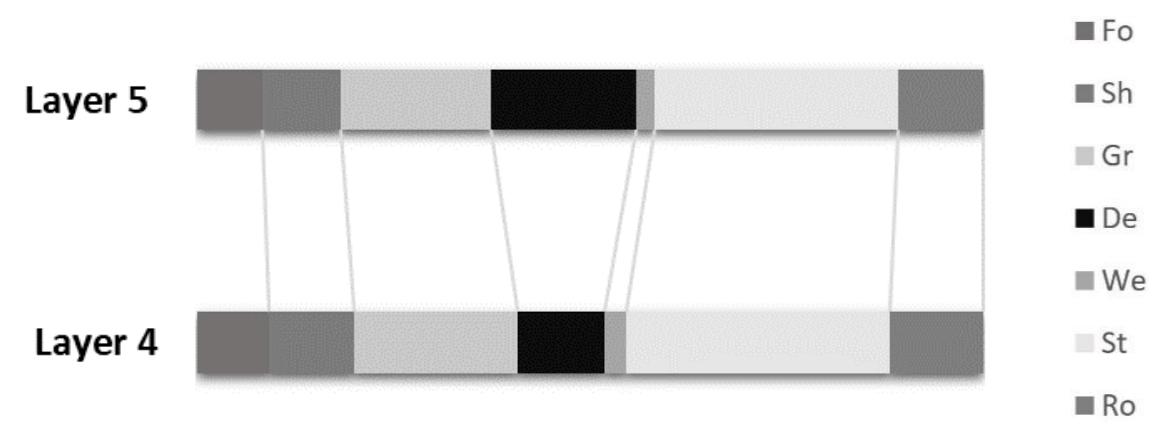

$\begin{array}{llllll}0 \% & 20 \% & 40 \% & 60 \% & 80 \% & 100 \%\end{array}$

Figure 3: Results of the habitat weighting method for Kaldar Cave (Layer 4 and Layer 5). Forest (Fo), Shrubland (Sh), Grassland (Gr), Desert (De), Wetland (We), Steppe (St) and Rocky (Ro).

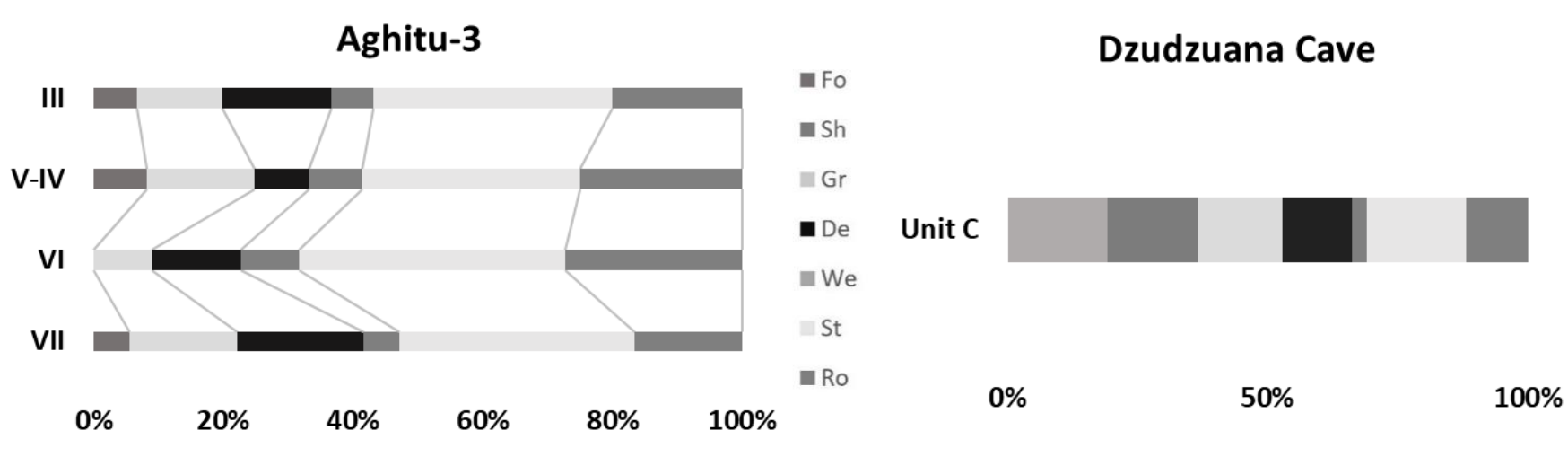

Figure 4: Results of the habitat weighting method for Aghitu-3 and Dzudzuana Cave. Forest (Fo), Shrubland (Sh), Grassland (Gr), Desert (De), Wetland (We), Steppe (St) and Rocky (Ro). 


\begin{tabular}{|c|c|c|c|c|c|c|c|}
\hline Species & Fo & Sh & Gr & De & We & St & Ro \\
\hline Ellobius lutescens & & & 0.33 & 0.33 & & 0.33 & \\
\hline Ellobius fuscocapillus & & & & & & 1 & \\
\hline Microtus irani & & & 1 & & & & \\
\hline Microtus guentheri & & & 1 & & & & \\
\hline Microtus socialis & & 0.5 & & & & 0.5 & \\
\hline Chionomys nivalis & & & & & & & 1 \\
\hline Cricetulus migratorius & & & 0.33 & 0.33 & & 0.33 & \\
\hline Mesocricetus brandti & & & & & & 1 & \\
\hline Meriones persicus & & 0.33 & 0.33 & & & & 0.33 \\
\hline Allactaga sp. & & & & 0.5 & & 0.5 & \\
\hline Apodemus sp. & 1 & & & & & & \\
\hline Mus musculus & & 0.33 & 0.33 & & 0.33 & & \\
\hline Myomimus sp. & & & & 1 & & & \\
\hline
\end{tabular}

Table 1: scores attributed to each rodent species found at Kaldar Cave according to its ecological requirements, used for the habitat weighting method: Forest (Fo), Shrubland (Sh), Grassland (Gr), Desert (De), Wetland (We), Steppe (St) and Rocky (Ro).

\begin{tabular}{|c|c|c|c|c|c|c|c|c|c|c|}
\hline Species & | I & II & II/III & III & IV & V & VI & VII & VIII & IX \\
\hline Ellobius lutescens & & & & & & & & 1 & & \\
\hline Ellobius fuscocapillus & & & & 0.33 & 0.33 & & & 0.33 & & \\
\hline Microtus irani & & & & & 1 & & & & & \\
\hline Microtus socialis & & & & & 0.5 & & & 0.5 & & \\
\hline Chionomys nivalis & & & & & 0.25 & & 0.25 & & 0.25 & 0.25 \\
\hline Cricetulus migratorius & & & & & 0.33 & & 0.33 & 0.33 & & \\
\hline Mesocricetus brandti & & & & & 1 & & & & & \\
\hline Meriones persicus & & & & 0.5 & 0.5 & & & & & \\
\hline Allactaga sp. & & & & 0.5 & & & & 0.5 & & \\
\hline Apodemus sp. & & & & & & & 1 & & & \\
\hline Mus musculus & 0.11 & 0.11 & 0.11 & 0.11 & 0.11 & 0.11 & 0.11 & 0.11 & 0.11 & \\
\hline
\end{tabular}

Table 2: scores attributed to each rodent species found at Kaldar Cave for the bioclimatic model (in accordance with Hernández-Fernández, 2001; HernándezFernández et al., 2007). See text for the significance of the Roman numerals corresponding to the climatic groups. 


\begin{tabular}{l|ccc|ccc|ccc} 
& \multicolumn{4}{|c|}{ Layer 5 } & \multicolumn{3}{c|}{ Layer 4 } & \multicolumn{3}{c}{ Layers 1-3 } \\
\cline { 2 - 10 } Taxon & NISP & MNI & \% & NISP & MNI & $\%$ & NISP & MNI & $\%$ \\
\hline Indet. & 3 & - & - & 11 & - & - & - & - & - \\
Microtus spp. & 292 & 51 & 52.33 & 258 & 31 & 48.31 & 4 & 3 & 20 \\
Microtus irani & 14 & 9 & 2.51 & 0 & 0 & 0.00 & 1 & 1 & 5 \\
Microtus guentheri & 0 & 0 & 0.00 & 16 & 9 & 3.00 & 1 & 1 & 5 \\
Microtus socialis & 35 & 20 & 6.27 & 36 & 20 & 6.74 & 3 & 3 & 15 \\
Chionomys nivalis & 6 & 3 & 1.08 & 17 & 12 & 3.18 & 2 & 1 & 10 \\
Ellobius spp. & 80 & 7 & 14.34 & 91 & 8 & 17.04 & 2 & 2 & 10 \\
Ellobius fuscocapillus & 5 & 4 & 0.90 & 5 & 3 & 0.94 & 1 & 1 & 5 \\
Ellobius lutescens & 10 & 6 & 1.79 & 10 & 7 & 1.87 & - & - & - \\
Cricetulus migratorius & 5 & 3 & 0.90 & 14 & 3 & 2.62 & 1 & 1 & 5 \\
Mesocricetus brandti & 7 & 4 & 1.25 & 3 & 1 & 0.56 & 0 & 0 & 0 \\
Meriones cf. persicus & 88 & 18 & 15.77 & 65 & 17 & 12.17 & 3 & 2 & 15 \\
Allactaga sp. & 1 & 1 & 0.18 & 1 & 1 & 0.19 & 0 & 0 & 0 \\
Myomimus sp. & 5 & 3 & 0.90 & 0 & 0 & 0.00 & 0 & 0 & 0 \\
Apodemus sp. & 5 & 2 & 0.90 & 6 & 3 & 1.12 & 2 & 1 & 10 \\
Mus cf. musculus & 2 & 1 & 0.36 & 1 & 1 & 0.19 & 0 & 0 & 0 \\
\hline Total & $\mathbf{5 5 8}$ & $\mathbf{1 3 2}$ & 100.00 & $\mathbf{5 3 4}$ & $\mathbf{1 1 6}$ & 100.00 & $\mathbf{2 0}$ & $\mathbf{1 6}$ & 100.00
\end{tabular}

Table 3: Representation of the Kaldar Cave rodent species in terms of number of identified specimens (NISP), minimum number of individuals (MNI) and percentage of the NISP (\%). 


\begin{tabular}{|c|c|c|c|c|c|c|c|c|c|}
\hline \multirow[t]{2}{*}{ Species } & \multirow[t]{2}{*}{ NS } & \multicolumn{2}{|c|}{ L (Length) } & \multicolumn{2}{|c|}{ La (Width T4) } & \multicolumn{2}{|c|}{ Li (Width T5) } & \multicolumn{2}{|c|}{ Total Width } \\
\hline & & Mean & Min-Max & Mean & Min-Max & Mean & Min-max & Mean & Max-Min \\
\hline Reference collection & & & & & & & & & \\
\hline Microtus irani & 4 & 3.06 & $2.98-3.23$ & 0.42 & $0.40-0.44$ & 0.64 & $0.62-0.67$ & 1.06 & $1.03-1.08$ \\
\hline Microtus socialis & 69 & 2.78 & $2.29-3.34$ & 0.42 & $0.32-0.51$ & 0.6 & $0.44-0.73$ & 1.02 & $0.78-1.19$ \\
\hline Microtus arvalis & 25 & 2.72 & $2.45-2.96$ & 0.39 & $0.32-0.46$ & 0.6 & $0.50-0.70$ & 1 & $0.83-1.13$ \\
\hline Microtus guentheri & 70 & 2.58 & 2.2-3 & & & & & & \\
\hline Kaldar Cave & & & & & & & & & \\
\hline Microtus guentheri & 17 & 2.52 & 2.18-3.01 & 0.35 & $0.27-0.43$ & 0.54 & $0.40-0.68$ & 0.90 & $0.70-1.10$ \\
\hline Microtus irani & 15 & 2.89 & 2.52-3.39 & 0.41 & $0.37-0.50$ & 0.62 & $0.54-0.70$ & 1.05 & $0.92-1.18$ \\
\hline Microtus socialis & 74 & 2.54 & $2.06-3.01$ & 0.37 & $0.28-0.48$ & 0.55 & $0.40-0.70$ & 0.92 & $0.70-1.16$ \\
\hline
\end{tabular}

Table 4: Measurements of Microtus specimens (in mm): NS, number of specimens; L, length; La, T4 width; Li, T5 width. 


\begin{tabular}{|c|c|c|c|c|c|c|c|c|c|}
\hline & \multicolumn{4}{|c|}{ Ellobius fuscocapillus } & \multicolumn{2}{|c|}{ Ellobius lutescens } & \multicolumn{2}{|c|}{ Ellobius talpinus } \\
\hline & & $\begin{array}{l}\text { Layer } 5 \\
\mathrm{NISP}=5\end{array}$ & $\begin{array}{l}\text { Layer } 4 \\
\text { NISP }=5\end{array}$ & $\begin{array}{c}\text { Layer } 1-3 \\
\text { NISP }=1\end{array}$ & $\begin{array}{c}\text { NHM } \\
\text { NISP=12 }\end{array}$ & $\begin{array}{l}\text { Layer } 5 \\
\text { NISP }=9\end{array}$ & $\begin{array}{c}\text { Layer } 4 \\
\text { NISP }=10\end{array}$ & $\begin{array}{c}\text { NHM } \\
\text { NISP=14 }\end{array}$ & $\begin{array}{c}\text { NHM } \\
\text { NISP=14 }\end{array}$ \\
\hline \multirow{2}{*}{$\mathbf{L}$} & Min-Max & $3.29-3.84$ & $3.73-3.74$ & - & $3.06-4.05$ & $3.08-3.32$ & $3.05-3.4$ & $3.07-3.3$ & $2.86-3.35$ \\
\hline & Mean & 3.45 & 3.74 & - & 3.53 & 3.28 & 3.29 & 3.21 & 3.12 \\
\hline \multirow{2}{*}{ W } & Min-Max & $1.32-1.51$ & $1.40-1.54$ & - & $1.3-1.59$ & $1.20-1.45$ & $1.13-1.48$ & $1.11-1.52$ & $1.09-1.72$ \\
\hline & Mean & 1.45 & 1.48 & 1.5 & 1.41 & 1.34 & 1.32 & 1.34 & 1.24 \\
\hline
\end{tabular}

Table 5: Measurements of Ellobius specimens (in $\mathrm{mm}$ ): L, total length; W, width. NHM: Natural History Museum of London. NISP: number of identified specimens.

\begin{tabular}{l|ccccc} 
& Layer 5 & SD & Layer 4 & SD & Current values \\
\hline Mean annual temperature & $10.90^{\circ} \mathrm{C}$ & 3.39 & $11.73^{\circ} \mathrm{C}$ & 3.39 & $16.90^{\circ} \mathrm{C}$ \\
Maximum mean temperature & $23.45^{\circ} \mathrm{C}$ & 4.77 & $23.10^{\circ} \mathrm{C}$ & 4.77 & $29.60^{\circ} \mathrm{C}$ \\
Minimum mean temperature & $-1.69^{\circ} \mathrm{C}$ & 4.66 & $0.25^{\circ} \mathrm{C}$ & 4.66 & $5 \div \mathrm{C}$ \\
Mean annual precipitation & $258.68 \mathrm{~mm}$ & $533.24 \mathrm{~mm}$ & $104.08 \mathrm{~mm}$ & $533.24 \mathrm{~mm}$ & $488 \mathrm{~mm}$
\end{tabular}

Table 6: Bioclimatic model estimates for Kaldar Cave. SD, standard deviation. Current values obtained from: https://en.climatedata.org/asia/iran/lorestan/khorramabad-764550/. 


\begin{tabular}{|c|c|c|c|c|c|}
\hline Site/Author & Layer & $\begin{array}{l}\text { Human } \\
\text { culture }\end{array}$ & Chronology & Environmental conditions & Rodent \\
\hline $\begin{array}{l}\text { Amud Cave } \\
\text { (Belmaker and Hovers, }\end{array}$ & B4 & Neanderthals & $68.5 \pm 3.4 \mathrm{ka}$ & Grassland vegetation & Microtus guentheri \\
\hline 2011) & B2-B1 & Neanderthals & $\begin{array}{l}56.5 \pm 3.5,57.6 \pm \\
3.7, \text { respectively }\end{array}$ & Woodland & $\begin{array}{l}\text { Apodemus cf. mystacinus } \\
\text { and Mus macedonicus }\end{array}$ \\
\hline $\begin{array}{l}\text { Dzudzuana Cave } \\
\text { (Belmaker et al., 2016) }\end{array}$ & Unit C & $\begin{array}{l}\text { Modern } \\
\text { human }\end{array}$ & 27-24ka cal BP & Mild and humid & $\begin{array}{l}\text { Microtus, Ellobius, Arvicola, } \\
\text { Apodemus and Allactaga. }\end{array}$ \\
\hline $\begin{array}{l}\text { Aghitu-3 } \\
\text { (Djamali et al., 2008; } \\
\text { Kandel et al., 2017) }\end{array}$ & $\begin{array}{l}\text { Level } \\
\text { VII-III }\end{array}$ & $\begin{array}{l}\text { Modern } \\
\text { human }\end{array}$ & $\begin{array}{l}\text { The oldest layer is VII with a } \\
\text { chronology between } 39 \text { - } \\
36,000 \text { cal BP and the most } \\
\text { recent is layer III, between } \\
29-24,000 \text { cal BP }\end{array}$ & $\begin{array}{l}\text { This sequence documents } \\
\text { that the climate becomes } \\
\text { colder }\end{array}$ & $\begin{array}{l}\text { Microtus spp., Chionomys } \\
\text { sp., Arvicola amphibius and } \\
\text { Ellobius lutescens }\end{array}$ \\
\hline
\end{tabular}

Table 7: Comparison between Middle Eastern sites with small-mammal studies 


\begin{tabular}{|c|c|c|c|c|c|c|c|c|}
\hline & \multicolumn{3}{|c|}{ Kaldar Cave } & \multicolumn{3}{|c|}{ Aghitu-3 } & \multicolumn{2}{|c|}{ Dzudzuana } \\
\hline Taxon & Layers 1-3 & Layer 4 & Layer 5 & VII & VI & V-IV & III & Unit C \\
\hline Microtus spp. & $\mathrm{x}$ & $\mathrm{X}$ & $\mathrm{X}$ & $\mathrm{X}$ & $\mathrm{X}$ & $\mathrm{X}$ & $\mathrm{X}$ & \\
\hline Microtus cf. arvalis & & & & & & & & $\mathrm{x}$ \\
\hline Microtus irani & $x$ & & $\mathrm{x}$ & & & & & \\
\hline Microtus guentheri & $x$ & $X$ & & & & & & \\
\hline Microtus socialis & $\mathrm{X}$ & $\mathrm{X}$ & $\mathrm{x}$ & & & & & \\
\hline Chionomys nivalis & - & $\mathrm{x}$ & $x$ & $x$ & $\mathrm{x}$ & $\mathrm{x}$ & $\mathrm{x}$ & $\mathrm{x}$ \\
\hline Clethrionomys glareolus & & & & & & & & $\mathrm{x}$ \\
\hline Ellobius spp. & $\mathrm{X}$ & $\mathrm{X}$ & $\mathrm{X}$ & & & & & \\
\hline Ellobius fuscocapillus & $\mathrm{X}$ & $\mathrm{X}$ & $\mathrm{X}$ & & & & & \\
\hline Ellobius lutescens & - & $x$ & $x$ & $\mathrm{x}$ & & & & $\mathrm{x}$ \\
\hline Cricetus cricetus & & & & & & & & $x$ \\
\hline Cricetulus migratorius & $x$ & $x$ & $x$ & $\mathrm{x}$ & & $x$ & $\mathrm{X}$ & $\mathrm{x}$ \\
\hline Mesocricetus brandti & & $\mathrm{X}$ & $\mathrm{X}$ & $\mathrm{x}$ & $\mathrm{x}$ & $\mathrm{x}$ & $\mathrm{x}$ & $\mathrm{x}$ \\
\hline Meriones cf. persicus & $\mathrm{x}$ & $\mathrm{x}$ & $\mathrm{x}$ & & & & & \\
\hline Allactaga sp. & & $\mathrm{X}$ & $\mathrm{X}$ & $x$ & $x$ & & $\mathrm{X}$ & $\mathrm{x}$ \\
\hline Myomimus sp. & & & $x$ & & & & & \\
\hline Apodemus sp. & $\mathrm{X}$ & $\mathrm{X}$ & $\mathrm{X}$ & & & & & $\mathrm{x}$ \\
\hline Mus musculus & & $\mathrm{X}$ & $\mathrm{X}$ & & & & & $\mathrm{X}$ \\
\hline Arvicola amphibius & & & & $\mathrm{x}$ & $\mathrm{X}$ & $\mathrm{X}$ & $\mathrm{X}$ & $\mathrm{X}$ \\
\hline
\end{tabular}

Table 8: comparison of the small-mammal lists from several Upper Palaeolithic sites in the Middle East. 


\begin{tabular}{|c|c|c|c|c|c|c|c|c|c|}
\hline & \multicolumn{6}{|c|}{ Aghitu-3 } & \multicolumn{3}{|c|}{ Dzudzuana Cave } \\
\hline & VII & VI & V-IV & III & SD & $\begin{array}{l}\text { Current } \\
\text { Values }\end{array}$ & Unit C & SD & $\begin{array}{l}\text { Current } \\
\text { Values }\end{array}$ \\
\hline Mean annual Temperature & $15.46^{\circ} \mathrm{C}$ & $19.44^{\circ} \mathrm{C}$ & $19.21^{\circ} \mathrm{C}$ & $17.87^{\circ} \mathrm{C}$ & 3.386 & $8.5^{\circ} \mathrm{C}$ & 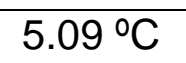 & 3.39 & $9.7^{\circ} \mathrm{C}$ \\
\hline Maximum mean temperature & $23.59{ }^{\circ} \mathrm{C}$ & $24.44^{\circ} \mathrm{C}$ & $24.09 \stackrel{\circ}{ } \mathrm{C}$ & $24 \stackrel{\circ}{ } \mathrm{C}$ & 4.772 & $20.2{ }^{\circ} \mathrm{C}$ & $18.55^{\circ} \mathrm{C}$ & 4.77 & $20.3^{\circ} \mathrm{C}$ \\
\hline Minimum mean temperature & $7.31^{\circ} \mathrm{C}$ & $14.67^{\circ} \mathrm{C}$ & $14.72^{\circ} \mathrm{C}$ & $11.96{ }^{\circ} \mathrm{C}$ & 4.656 & $-3.8 \stackrel{\circ}{C}$ & $-8.26^{\circ} \mathrm{C}$ & 4.66 & $-1.6^{\circ} \mathrm{C}$ \\
\hline Mean annual precipitation & $\begin{array}{c}1169.04 \\
\mathrm{~mm}\end{array}$ & $\begin{array}{c}1729.48 \\
\mathrm{~mm}\end{array}$ & $\begin{array}{c}1825.99 \\
\mathrm{~mm}\end{array}$ & $\begin{array}{c}1484.60 \\
\mathrm{~mm}\end{array}$ & 533.236 & $532 \stackrel{\circ}{C}$ & $\begin{array}{c}194.98 \\
\mathrm{~mm}\end{array}$ & 533.24 & $868 \mathrm{~mm}$ \\
\hline
\end{tabular}

Table 9: Estimates using the bioclimatic method for Aghitu-3 and Dzudzuana Cave. SD, standard deviation. Current values obtained from Kandel et al. (2017) for Aghitu-3 and https://es.climate-data.org/asia/georgia/imereti/jria-414325/?amp=true for Dzudzuana Cave. 
